\title{
BRACONIDAE (HYMENOPTERA) FROM KOREA, XXIV. SPECIES OF THIRTEEN SUBFAMILIES
}

\author{
JENô PAPp † \\ Department of Zoology, Hungarian Natural History Museum \\ H-1088 Budapest, Baross u. 13, Hungary
}

Sixty-five braconid species from the Korean Peninsula are recorded for the present elaboration. The species are divided in thirteen subfamilies. Descriptions of five new species: Bracon acunens sp. n., Bracon bitumor sp. n., Aleiodes subcompressus sp. n., Chelonus moczari sp. n. and Blacus pentagonus sp. n. are provided. Twenty-five species are new records for the fauna of Korea. Detailed collecting data are supplied to every species. The braconid material is housed in the Hungarian Natural History Museum, Budapest. With 88 linedrawn figures.

Key words: new species, descriptions, faunistic data.

\section{INTRODUCTION}

Sixty-five braconid species are reported from the Korean Peninsula based on 137 specimens. From among the 65 species five are new to science: Bracon (Ophthalmobracon) acunens sp. n., Bracon (Glabrobracon) bitumor sp. n., Aleiodes (Aleiodes) subcompressus sp. n., Chelonus moczari sp. n. and Blacus (Leioblacus) pentagonus sp. $\mathrm{n}$. The 65 species belong to thirteen subfamilies. Subsequently the subfamilies are enumerated in alphabetic order with indication of the respective species-number (sp.): Blacinae $1 \mathrm{sp}$. (new), Brachistinae $3 \mathrm{sp}$., Braconinae 35 sp. (2 new), Cheloninae 10 sp. (1 new), Doryctinae 1 sp., Euphorinae 4 sp., Exothecinae 1 sp., Hormiinae 1 sp., Macrocentrinae 1 sp., Meteorinae 2 sp., Orgilinae 1 sp., Rhyssalinae $1 \mathrm{sp}$. and Rogadinae 4 sp. (1 new). Twentyfive (mainly Bracon) species are new to the fauna of the Korean Peninsula.

In the descriptions the following abbreviations are applied after van AchterberG (1993: 5 Figs H-K):

Ocelli - OOL = ocellar-ocular line, i.e., shortest distance between hind ocellus and compound eye; $\mathrm{POL}=$ postocellar line, i.e., shortest distance between hind two ocelli.

Fore wing $-m-c u=$ recurrent or transverse medio-cubital vein; $r=$ first section of the radial vein; $1-C U 1$ and $2-C U 1$ = first and second sections of the discoidal vein; $1-M=$ basal vein; $1-R 1$ = first section of the metacarpal vein; $1-S R-M=$ first section of the cubital vein; $2-S R=$ first transverse cubital vein, $3-S R=$ second section of the radial vein; $S R 1=$ third section of the radial vein.

The denomination of the variable surface microsculpture is adopted after EADY (1968) and HARRis (1979). Structure termionology is used after GAULD and Bolton (1988: 58-74). 


\section{BRACONINAE}

\section{Bracon (Ophthalmobracon) acunens sp. n.}

(Figs 1-11)

Material examined $(2++4 \lambda)$ - Female holotype and one female + one male paratypes: Korea, Gyenong Nam, Chinju City, Chojeon-dong, taken with light trap at night 0:00-03.00, 1 July 1993. - One male paratype: same locality, 1-2 July 1993. - One male paratype: same locality, 7-8 July 1993. - One male paratype: same locality, 25-26 July 1993. All six specimens were collected by Deok-Seo Ku.

Type condition - Holotype is in good condition: (1) glued on card point by its left meso- and metapleuron, (2) left hind leg somewhat less visible owing to the mounting. Five paratypes $(1++4 \hat{)})$ are also in good condition: (1) glued on card points by their left

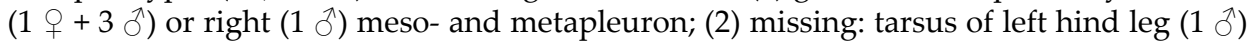
and tarsomeres $3-5$ of left hind leg $(1 \AA)$.

Type depository - Holotype and one female + four male paratypes are housed in the Hungarian Natural History Museum (Department of Zoology), Budapest; Hym. Typ. Nos 12266 (holotype) and 12267-12271 (paratypes).

Etymology - The new species received the name "acunens" which is an acronym of the reduction of the Latin "acu[tus cer]nens" (sharp eyed).

Description of the female holotype - Body $3.2 \mathrm{~mm}$ long. Antenna slightly shorter than body and with 23 antennomeres. First flagellomere 2.5 times and penultimate flagellomere 1.6 times as long as broad, flagellum faintly attenuating. - Head in dorsal view (Fig. 1), 1.8 times as broad as long, temple receded, eye 2.7 times longer than temple. Ocelli elliptic, OOL twice longer than POL. Malar space one-fourth shorter than basal width of mandible. Eye in lateral view nearly round, 1.3 times as high as wide, gena narrow, eye twice wider than gena (Fig. 2 see arrows). Face clearly twice wider than high, inner margin of eyes diverging ventrally. Oral opening elliptic: 1.5 times wider than shortest distance between opening and eye. Face, frons and vertex coriaceous, gena polished.

Mesosoma in lateral view 1.4 times as long as high. Notauli feebly distinct, parallel, posteriorly meeting in rugosity; otherwise mesoscutum densely punctate, interpunctures shorter than punctures and shiny. Scutellum somewhat less densely punctate, interpunctures shiny. Propodeum polished with a medio-longitudinal sulcus, above lunule rugulose (Fig. 3). Mesopleuron polished, prescutellar furrow indicated by coriaceous sculpture. Hind femur thick, 2.7 times as long as broad medially (Fig. 4).

Fore wing as long as body. Pterostigma 2.2 times as long as wide, issuing $r$ proximally from its middle, $r$ somewhat shorter than width of pterostigma (15:18), second submarginal cell long: 2-SR slightly shorter than 3-SR (22:25), SR1 2.4 times as long as 3-SR and reaching tip of wing (Fig. 5). First discal cell: $1-M$ and $1-S R-M$ meeting in obtuse angle, 1-M 2.2 times longer than $m-c u$ (Fig. 6 see arrow).

First tergite very broad, 1.25 times wider at rear than long or 0.8 times as long as wide posteriorly; second tergite 2.7 times as wide as long (laterally) and 1.45 times as long as third tergite, suture between tergites $2-3$ bisinuate (Fig. 7). Tergites strongly rugose. Ovipositor sheath somewhat longer than hind tarsus (40:35).

Scape and pedicel ochre yellow, flagellum blackish brown. Ground colour of body black with reach light pattern. Testaceous: lateral part of pronotum, posterior half of mesoscutum. Ochre yellow: face, clypeus and cheek. Palpi pale yellow. Straw yellow: second 
tergite except antero-median black macula, third and fourth tergites laterally. Tegula and parategula ochre. Legs 1-2 yellow; leg 3: coxa black, trochanters straw yellow, femur blackish, basally and apically blackish, tibia yellow and distally brownish fumous, tarsus brownish fumous. Wings subhyaline, pterostigma and veins dark brown, pterostigma with a small yellow macula.

Description of the female paratype - Similar to the female holotype. Body $3.5 \mathrm{~mm}$ long. Penultimate flagellomere 1.7 times as long as broad. Head in dorsal view 1.9 times as broad as long, eye 2.5 times longer than temple. Eye in lateral view 1.4 times as high
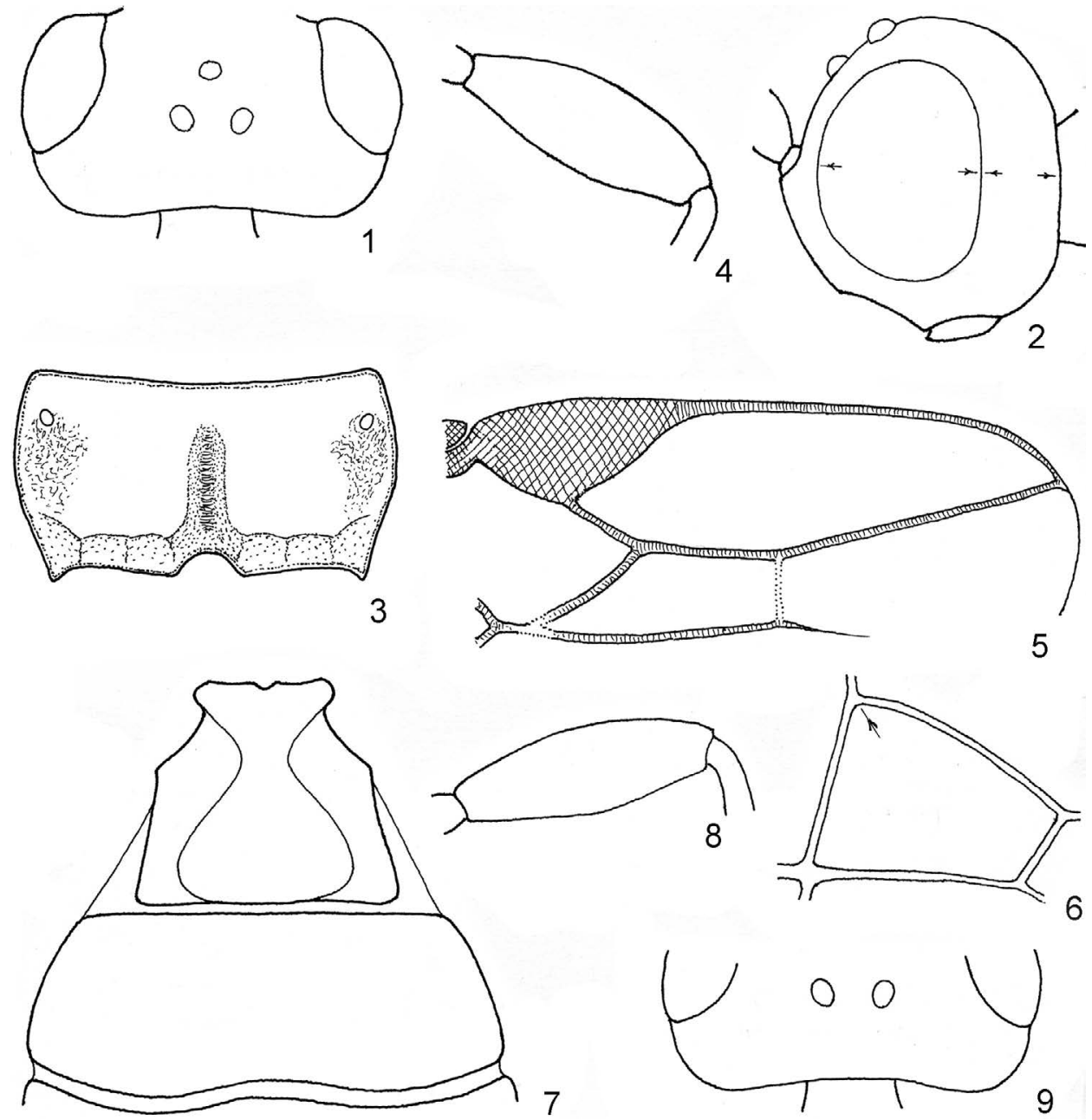

Figs 1-9. Bracon (Ophthalmobracon) acunens sp. n. (1-7: $q$ holotype, 8: + paratype, 9: $\widehat{o}$ paratype): 1 = head in dorsal view, 2 = head in lateral view, $3=$ propodeum, 4 = hind femur, $5=$ distal part of right fore wing, $6=$ first discal cell of fore wing, $7=$ tergites $1-2,8=$ hind femur, $9=$ temple in dorsal view 
as wide, narrow, eye 1.9 times wider than gena. Malar space one-third shorter than basal width of mandible. Fore wing: pterostigma 2.1 times as long as wide, issuing $r$ just proximally from its middle; 3-SR somewhat longer than 2-SR (25:23). Hind femur 3.1 times as long as broad just distally (Fig. 8). Suture beween tergites $2-3$ somewhat more bisinuate. Colouration similar to that of holotype.

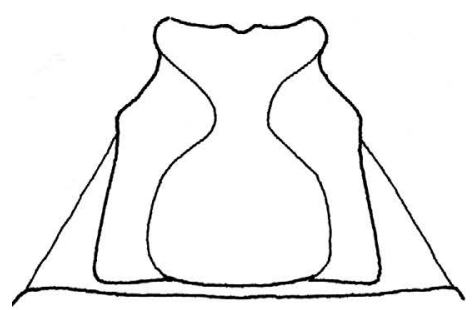

10

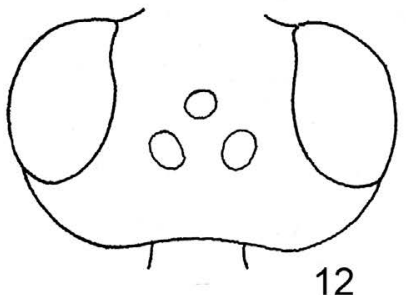

12

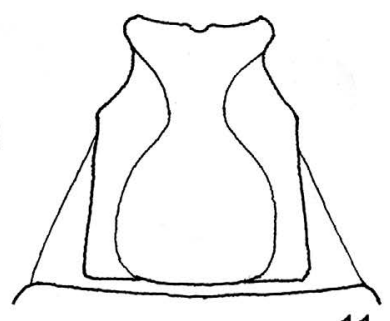

11
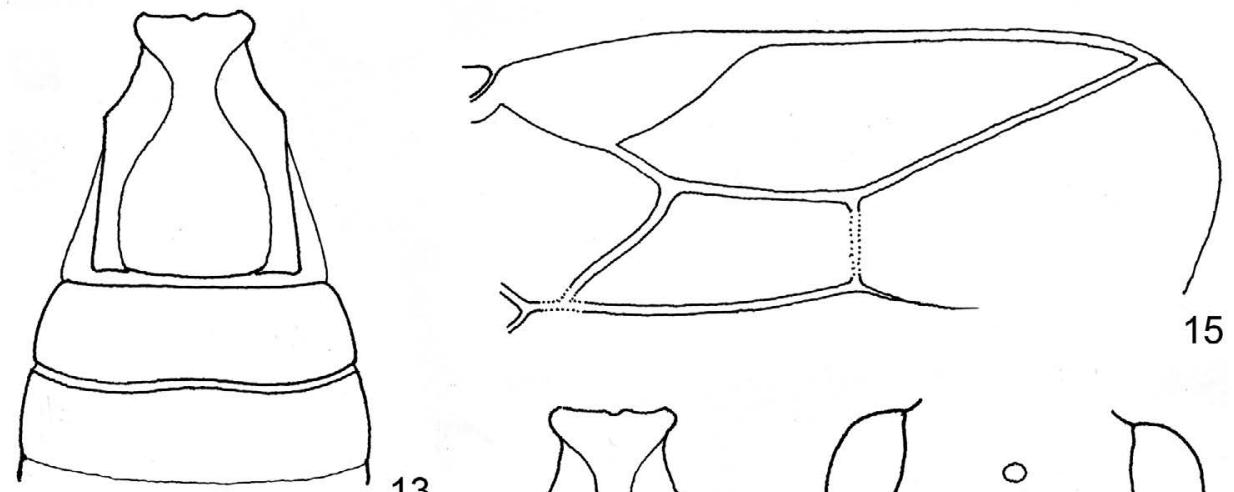

13

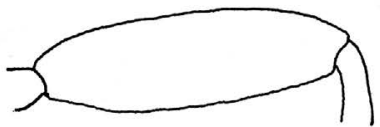

16
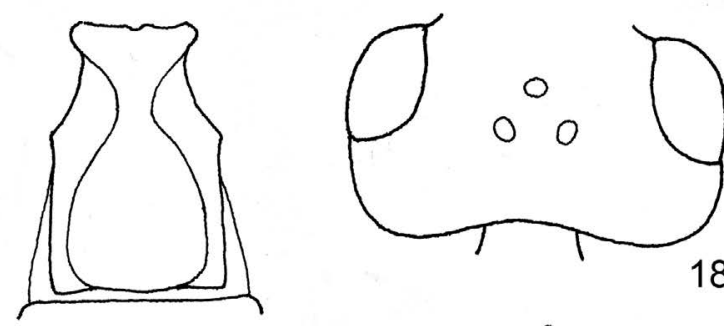

14

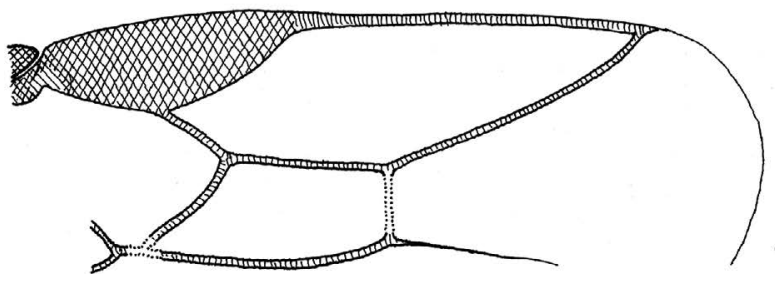

19

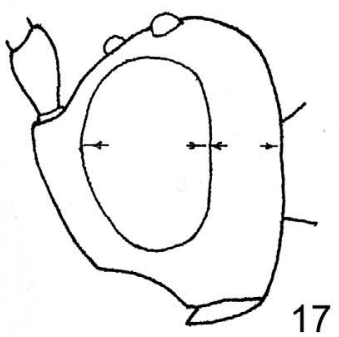

Figs 10-19. 10-11: Bracon (Ophthalmobracon) acunens sp. n.: first tergite (ð paratype). - 1216. Bracon (Ophthalmobacon) ophthalmicus Telenga (12-13, 15-16: + paratype; 14: đ paratype): 12 = head in dorsal view, 13 = tergites $1-3,14=$ tergite 1, $15=$ distal part of right fore wing, 16 = hind femur. - 17-19. Bracon (Sculptobracon) yakui Watanabe ( $Q$ ): 17 = head in lateral view, $18=$ head in dorsal view, $19=$ distal part of right fore wing 
Description of the four male paratypes - Similar to the female types. Body 2.2-2.7 $\mathrm{mm}$ long. Antenna shorter than to almost as long as body and with 19-24 antennomeres $(19: 1 \hat{\jmath}, 20: 1 \hat{\jmath}, 24: 1 \hat{\jmath})$. Penultimate flagellomere 2-2.3 times as long as broad $(2: 2 \hat{\jmath}, 2.3$ : 2 §). Head in dorsal view variably 1.7 to 1.85 times as broad as long, temple slightly less receded (Fig. 9). Anterior half of mesoscutum polished, its posterior half punctate (interpunctures shorter than punctures). Hind femur less thick, 3.3 times as long as broad medially or somewhat distally $(1 \bar{\jmath})$. Fore wing: pterostigma $2-2.5$ times as long as wide $(2: 1$ $\hat{\jmath}, 2.3: 2 \hat{\jmath}, 2.5: 1 \hat{\jmath})$. First tergite either somewhat broader at rear than long (45:40 Fig. 10) or somewhat longer than broad behind (40:36 Fig. 11). Suture between tergites $2-3$ almost straight. Dark colour of body more extended.

Taxonomic position - The new braconine species, Bracon (Ophthalmobracon) acunens sp. $\mathrm{n}$., is close to Bracon (Ophthalmobracon) ophthalmicus Telenga (Telenga 1933) considering their large compound eye (Figs 1-2,12), long submarginal cell of fore wing (Figs 5, 15), yellow tegula and legs 1-2; the distinction of the two species is keyed:

1 (2) Head in dorsal view somewhat less transverse, 1.6-1.7 times as broad as long, eye four times longer than temple, temple slightly more receded (Fig. 12). First tergite broadening posteriorly, 1.2 times longer than wide at rear or 0.8 times as wide behind as long, second tergite 3.3 times wider than long, tergites 2-3 equal in length (Fig. 13); that of the male: first tergite 1.3-1.4 times longer than broad (Fig. 14). Fore wing: $S R 1$ approaching tip of wing, 3-SR somewhat longer than 2-SR (Fig. 15). Antenna with 26 antennomeres. Hind femur 3.3 times ( 9 : Fig. 16) to 3.8 times ( ${ }^{\text {: }}$ Fig. 20) as long as broad. Body yellow.. : $2.5-3.5 \mathrm{~mm}$, ô: 2.3-2.4 mm. - Israel, Turkmenistan, Uzbekistan, Georgia, Mongolia Bracon (Ophthalmobracon) ophthalmicus Telenga, 1933

2 (1) Head in dorsal view somewhat more transverse, 1.8 times as broad as long, eye 2.7 times longer than temple, temple slightly less receded (Fig. 1). First tergite (Figs 7,10$)$ strongly broadening posteriorly, 1.25 times wider behind than long or 0.8 times as long as wide at rear; second tergite longer than third tergite. Fore wing: SR1 reaching tip of wing, 3-SR just longer than 2-SR (Fig. 5). Antenna with 23 antennomeres. Hind femur 2.5-2.9 times as long as broad (Figs 4), that of male: 3.1 times longer than broad (Fig. 8). Body black with straw yellow to testaceous pattern. o : 3.2-3.5 mm, ô: 2.2-2.7 mm. - Korea

Bracon (Ophthalmobracon) acunens sp. n.

The new species is also close to Bracon (Sculptobracon) yakui Watanabe considering their common traits: first tergite broad, second tergite longer than third tergite, tergites with strong sculpture, long submarginal cell of fore wing and dark coloured body; the distinction between the two species is as follows: 
1 (2) Tergites roughly and fairly evenly sculptured, eye usual in size (subgenus Sculptobracon). Eye in lateral view not large, 1.5-1.6 times as high as wide, 1.25-1.3 times wider than gena (Fig. 17 see arrows), eye in dorsal view 1.5-1.6 times longer than temple, temple rounded (Fig. 18). Fore wing: SR1 approaching tip of wing (Fig. 19), 1-M and $1-S R-M$ of first discal cell meeting in acute angle, 1-M 2-2.3 times longer than $m-c u$ (Fig. 21 see arrow). Second tergite medially with a polished field. Black colour of body somewhat less extended, i.e., body with more light colour pattern. + : 3.2-3.5 mm. - Russia, Japan, Korea

Bracon (Sculptobracon) yakui Watanabe, 1937

2 (1) Tergites less roughly sculptured, eye large (subgenus Ophthalmobracon). Eye in lateral view large, 1.3 times as high as wide, twice wider than gena (Fig. 2 see arrows), eye in dorsal view 2.7 times longer than temple, temple receded (Fig. 1). Fore wing: SR1 reaching tip of wing (Fig. 5), 1-M and $1-S R-M$ of first discal cell meeting in obtuse angle, 1-M 2.2 times onger than $m-c u$ (Fig. 6 see arrow). Second tergite medially without polished field. Body black with less light coloured pattern. + : 2.7-3(-3.7) $\mathrm{mm}$. Korea

Bracon (Ophthalmobracon) acunens sp. $\mathrm{n}$.

\section{Bracon (Glabrobracon) bitumor sp. n.}

(Figs 22-27)

Material examined - Male holotype: Korea, Pyongyang City, Daesong-san (san = montain), 16 June 1988, leg O. Merkl et Gy. Szél, loc. no. 1317. Holotype is in good condition: (1) glued on card point by its mesosternum, (2) missing: tarsomeres 3-5 of right middle and tarsus of right hind legs.

Type depository - Holotype is deposited in the Hungarian Natural History Museum (Department of Zoology), Budapest, Hym. Typ. No. 12272.

Etymology - The species name refer to the tumescence-shape two swellings of the face (Fig. 24).

Description of the male holotype - Body $2 \mathrm{~mm}$ long. Antenna as long as body ( $2 \mathrm{~mm})$ and with 22 antennomeres. Scape somewhat thick (Fig. 24). First flagellomere twice and penultimate flagellomere also twice as long as broad, flagellum faintly attenuating. - Head in dorsal view subcubic (Fig. 22), 1.5 times as broad as long, eye 1.3 times longer than temple, latter weakly rounded, occiput feebly excavated. Ocelli small and almost round, OOL 1.6 times as long as POL (Fig. 22). Eye in lateral view 1.5 times as high as wide, gena beyond eye narrowing ventrally, eye 1.3 times as wide as gena (Fig. 23 see arrows). Face quadrate: somewhat wider below antennal socket than high medially (Fig. 24 see arrows), inner margin of eyes converging ventrally; face (between eyes) with a apir of tumescenceshape swellings (Fig. 24). Horizontal diameter of oral opening about twice as long as shortest distance between opening and eye. Head polished.

Mesosoma in lateral view elongate, 1.6 times as long as high, polished. Notaulix faintly distinct on declivous anterior part of mesoscutum. Prescutellar furrow weak, smooth (i.e., not crenulated). Propodeum entirely smooth. - Hind femur thick, 3.1 times 
as long as broad medially, its lower margin almost straight (Fig. 25). Hind tibia one-fifth shorter than hind tarsus. Hind basitarsus slightly shorter than tarsomeres $2-4$ combined.

Fore wing slightly longer than body $(2.2 \mathrm{~mm})$. Pterostigma 2.6 times as long as wide and issuing $r$ just proximally from its middle, $r$ almost as long as width of pterostigma.
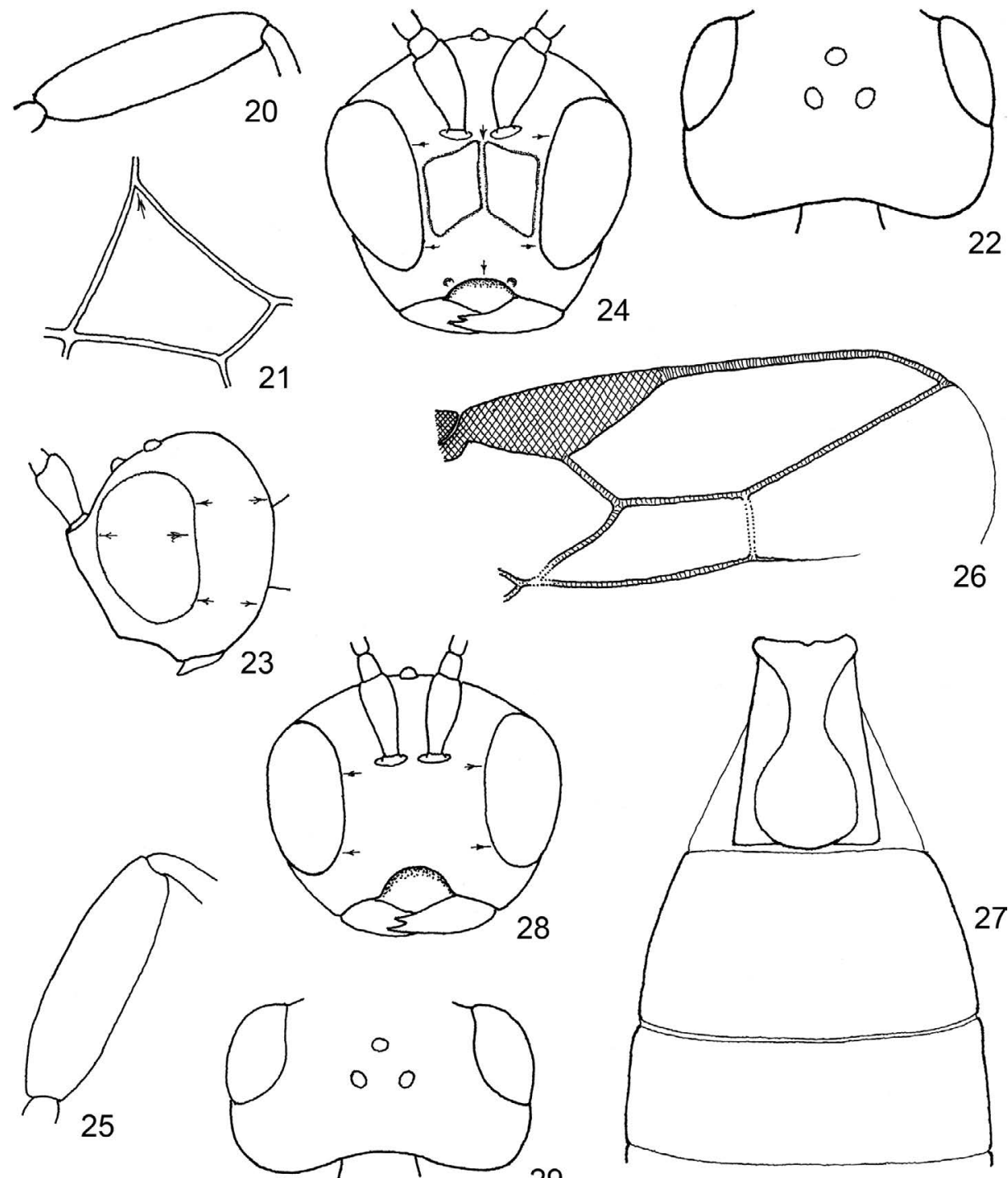

Figs 20-29. 20 = Bracon (Ophthalmobracon) ophthalmicus Telenga: hind femur. $-21=$ Bracon (Sculptobracon) yakui Watanabe: first discal cell (). . - 22-27. Bracon (Glabrobracon) bitumor sp. $n$. ( $\delta$ holotype): 22 = head in dorsal view, $23=$ head in lateral view, $24=$ head in frontal view, $25=$ hind femur, 26 = distal part of right fore wing, $27=$ tergites $1-3 .-28-29$. Bracon (Glabrobracon) claripennis Thomson ( + ): $28=$ head in frontal view, $29=$ head in dorsal view 
3-SR almost twice longer than $r, 3-S R$ a bit longer than 2-SR, SR1 straight, twice longer than $3-S R$ and reaching tip of wing (Fig. 26). First discal cell less high, $1-M$ twice as long as $m-\mathrm{cu}$.

First tergite long, 1.3 times as long as broad, evenly and weakly broadening posteriorly, smooth and shiny. Second tergite 1.5 times longer than third tergite, suture between them straight and smooth (i.e., not crenulated), together with further tergites polished (Fig. 27).

Body and legs fully black, except pair of yellow facial tumescence-shape swellings. Wings brown fumous. Pterostigma opaque brownish, veins light brownish.

Female and host unknown.

Distribution - Korea.

Taxonomic position - The braconine new species, Bracon (Glabrobracon) bitumor, is close to $B$. (Gl.) claripennis Thomson considering their common features: head in dorsal view less transverse (Figs 22, 29), ground colour of body black; the two species differ from each other as follows:

1 (2) Face close below pair of antennal sockets with a pair of tumescenceshape swellings; inner margin of eyes converging ventrally (Fig. 24 see arrows). Head in dorsal view subcubic: 1.5 times as broad as long, eye 1.3 times longer than temple (Fig. 22). Fore wing: $r$ almost as long as width of pterostigma, 3-SR a bit longer than 2-SR, SR1 twice as long as 3-SR (Fig. 26). Legs fully blackish. 0 : $2 \mathrm{~mm}$. - Korea

Bracon (Glabrobracon) bitumor sp. n.

2 (1) Face without swelling as usually; inner margin of eyes parallel (Fig. 28 see arrows). Head in dorsal view less cubic, 1.7(-1.8) times as broad as long, eye 1.5 times longer than temple (Fig. 29). Fore wing: $r$ clearly shorter than width of pterostigma, 3-SR 1.7-1.8 times as long as 2-SR, $S R 1$ less than twice as long as 3-SR (45:32, Fig. 30). Legs (usually) yellow, coxae dark. $\sigma^{\text {Tे }}$ : 1.8-2.2 mm. - Europe

Bracon (Glabrobracon) claripennis Thomson, 1894

With the key to the Bracon species of Asiatic Russia (Товіаs \& ВецоковYLSKIJ 2000: 113-164) Bracon (Glabrobracon) bitumor runs to B. (Gl.) nigropterus Tobias, the two species are distinguished by the features keyed (B. nigripterus known only by its description):

1 (2) Face quadrate: somewhat wider than high (Fig. 24 see arrows), inner margin of eyes converging ventrally; face with a pair of tumescenceshape swellings. Hind femur 3.1 times as long as broad (Fig. 25). Second tergite 1.5 times longer than third tergite (Fig. 27). Fore leg entirely black. Body black, only facial swellings yellow. $\delta^{\top}: 2 \mathrm{~mm}$. - Korea

Bracon (Glabrobracon) bitumor sp. n. 
2 (1) Face wide: 2.3 times wider than high, inner margin of eyes faintly converging ventrally; face without swellings. Hind femur four times as long as broad. Tergites 2-3 equal in length. Fore leg brownish yellow, head and mesosoma black with brownish yellow pattern. $9: 4 \mathrm{~mm}$. - Asiatic Russia: Primorski krai Bracon (Glabrobracon) nigropterus Tobias, 2000

Taxonomic remark - The new species, B. (Gl.) bitumor sp. n., is separated by a few features from $B$. (Gl.) nigropterus. The morphological distinction of the two species seems firmly supported, however, critical arguments may raise against the species validity of B. bitumor: (1) The holotype "bitumor" may represent the male sex of nigropterus (by the unusual facial trait), the latter species (i.e., B. nigropterus), contrarily, is known only by the female holotype. (2) The facial swelling may restrict to the male form. (3) The subcubic head in dorsal view (Fig. 67/1 in Tobias \& Belokobylskij 2000: 144; Fig. 22), the elongate mesosoma (1.5 times as long as high), the length of first tergite, black coloured body and brown fumous wings, i.e., the common features of the two species imply unintentionally their supposed specific identity. More specimens: females and males as well as reared material of them are needed to decide unambiguously whether we are confronting one or two species. Currently I consider the two holotype-forms as representing two distinct species.

\section{Rogadinae \\ Aleiodes (Aleiodes) subcompressus sp. n.}

(Figs 31-34, 40-41)

Material examined - Female holotype: Korea, prov. Pyongyang, Samji-yon, Park, taken with lamp at night, 5 June 1985, leg. A. Vojnits et L. Zombori, loc. no. 1005. Holotype is in good condition: glued on card point by its mesosternum.

Type depository - Holotype is deposited in the Hungarian Natural History Museum (Department of Zoology), Budapest, Hym. Typ. No. 12273.

Etymology - The new species received the name "subcompressus" refering to the weakly and laterally compressed metasoma.

Description of the female holotype - Body $4.8 \mathrm{~mm}$ long. Antenna as long as body and with 35 antennomeres. First flagellomere 1.8 times as long as broad, further flagellomeres shortening and attenuating so that penultimate flagellomere twice as long as broad (Fig. 41). - Head in dorsal view transverse (Fig. 31), 1.9 times as broad as long, eye somewhat protruding and 2.5 times as long as temple, temple receded. Ocelli large: POL shorter than greatest diameter of an ocellus (5:6). Eye in lateral view 1.7 times as high as wide and twice wider than gena (Fig. 32 see arrows). Malar space as long as basal width of mandible. Face 1.7 times wider than high.

Mesosoma in lateral view 1.6 times as long as high. Notaulix weakly distinct. Mesosoma coriaceous. Propodeum rugulose with a medio-longitudinal carina. Hind femur 3.8 times as long as broad medially (Fig. 33). Hind basitarsus as long as tarsomeres $2-3$ combined. 

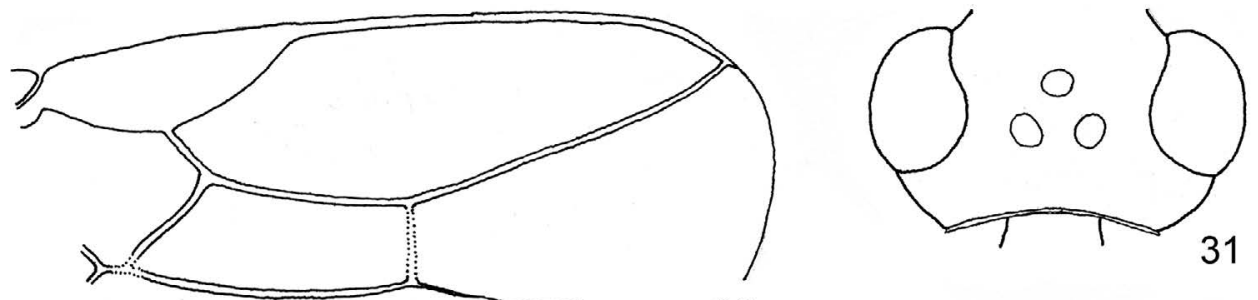

30
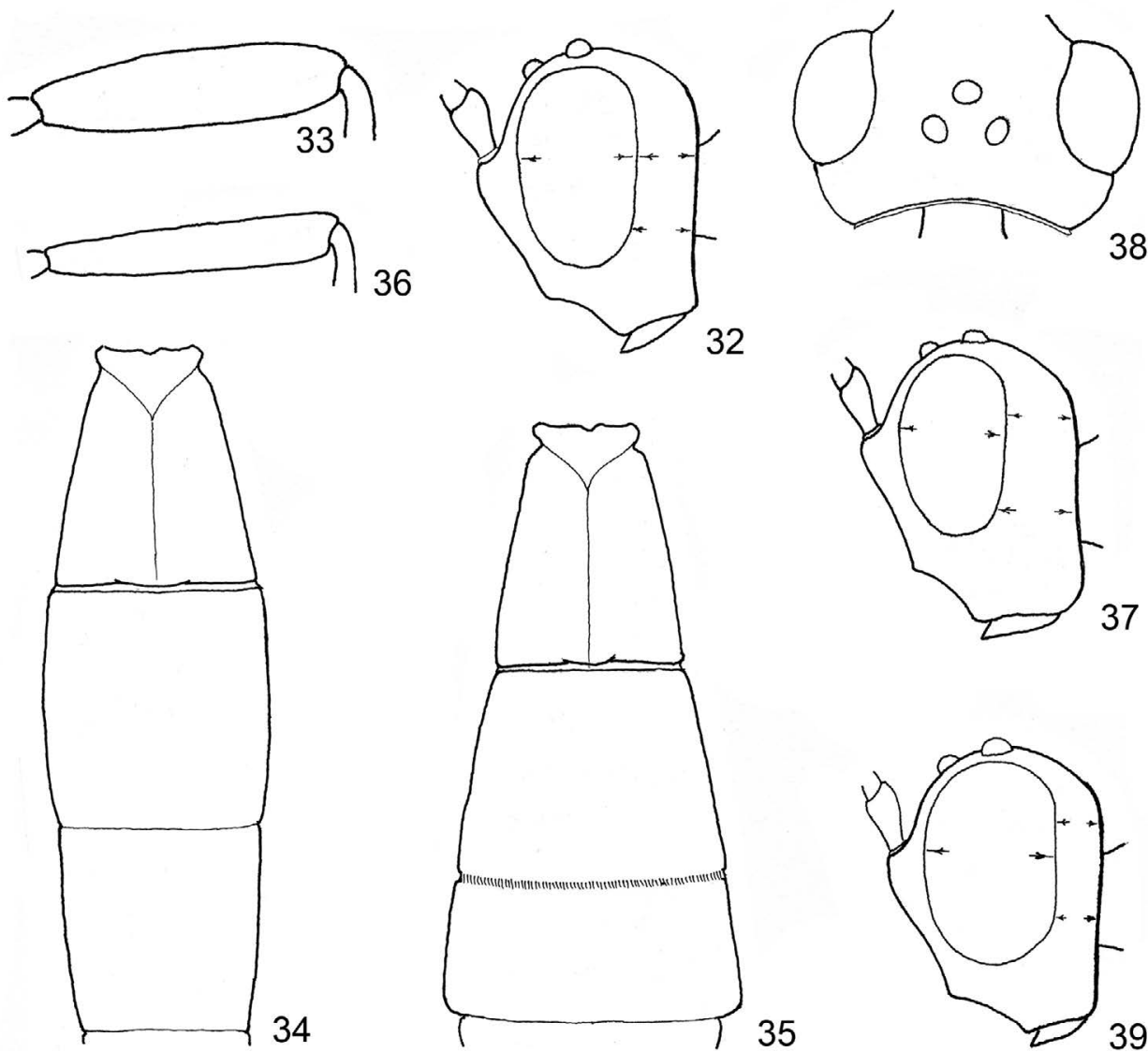

35

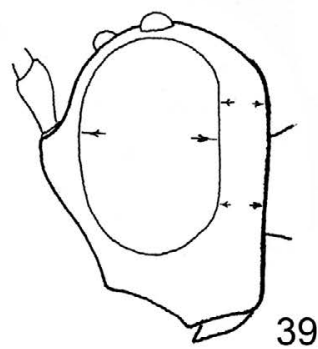

Figs 30-39. -30 = Bracon (Glabrobracon) claripennis Thomson ()): distal part of right fore wing. - 31-34. Aleiodes (Aleiodes) subcompressus sp. n. (q holotype): $31=$ head in dorsal view, $32=$ head in lateral view, $33=$ hind femur, $34=$ tergites $1-3 .-35-38$. Aleiodes (Aleiodes) angustatus (Papp) ( $q$ holotype): $35=$ tergites $1-3,36=$ hind femur, $37=$ head in lateral view, 38 = head in dorsal view. -39 . Aleiodes (Aleiodes) pallidator (Thunberg) ( $(+)$ : head in lateral view 


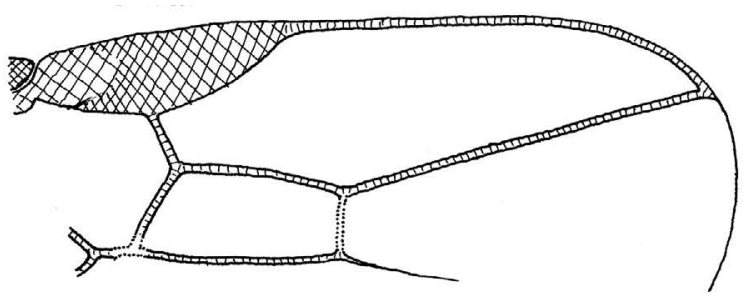

40

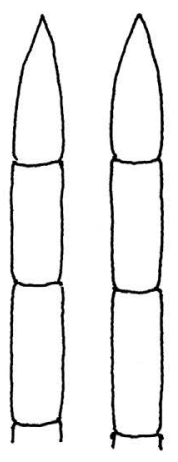

45
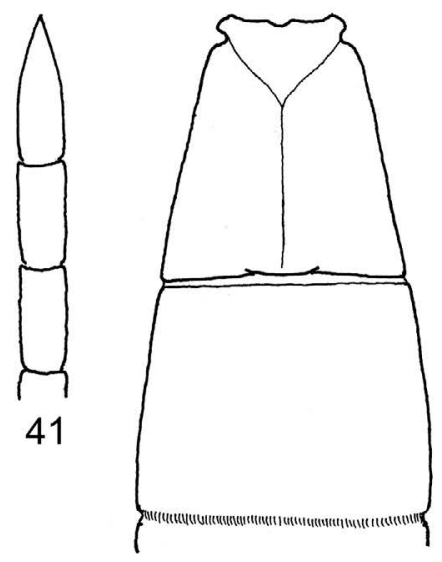

42

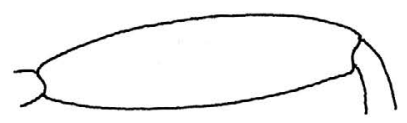

44
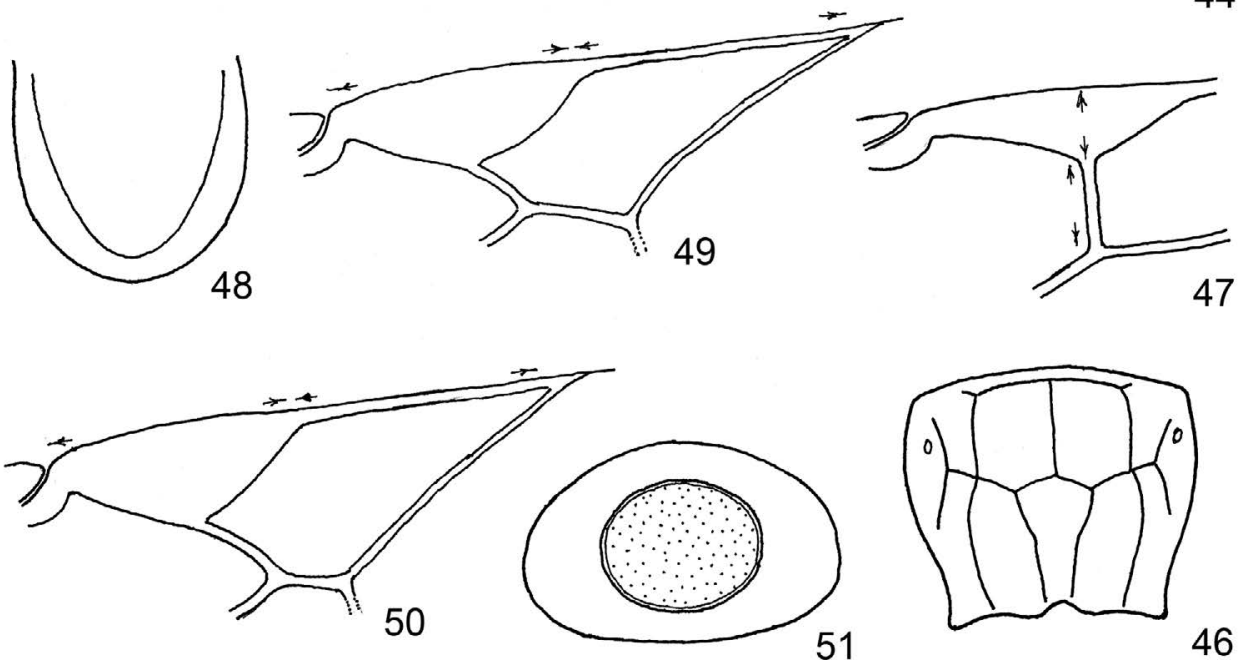

Figs 40-51. 40-41. Aleiodes (Aleiodes) subcompressus sp. n. (ㅇ holotype): $40=$ distal part of right fore wing, $41=$ ultimate three flagellomeres. $-42-45$. Aleiodes (Aleiodes) pallidator (Thunberg) ( + ): 42 = tergites 1-2, 43 = head in dorsal view, $44=$ hind femur, $45=$ ultimate three flagellomeres. $-46-47$. Blacus (Leioblacus) fischeri Haeselbarth ( + ): $46=$ propodeum, 47 = distal part of right fore wing. -48 . Chelonus moczari sp. n. ( $q$ holotype): posterior half of carapace in ventral view. -49 . Chelonus asiaticus Telenga $(+\hat{\jmath})$ : distal part of right fore wing. - 50. Chelonus formosanus Sonan ( + ): distal part of right fore wing. - 51. Microchelonus koreanus Tobias $\left({ }^{\lambda}\right)$ : apical foramen of carapace 
Fore wing somewhat shorter than body: $4.2 \mathrm{~mm}$ long. Pterostigma 3.3 times as long as wide, issuing $r$ proximally from its middle, $r$ shorter than width of pterostigma (9:12), 3$S R$ 1.8-1.9 times longer than 2-SR, 2-SR 2.7 times longer than $r, S R 1$ straight and reaching tip of wing (Fig. 40). 2-CU1 twice longer than 1-CU1.

First tergite somewhat longer than broad (40:35) and evenly broadening posteriorly, second tergite long, 1.3 times as long as broad and narrowing posteriorly (Fig. 34). Metasoma beyond second tergite laterally weakly compressed. Third tergite quadrate: as long as broad basally. Tergites 1-3 longitadinally striated, interstriations rugulo-subrugulose, further tergites coriaceous. Ovipositor sheath short, as long as hind basitarsus.

Antenna proximo-distally testaceous to dark brown. Body testaceous. Palpi and tegula yellow. Legs ochre. Propodeum and first tergite with blackish suffusion. Wings subhyaline, pterostigma brownish, basally yellow. Veins brownish.

Male and host unknown.

Distribution - Korea.

Taxonomic position - The rogadine new species, Aleiodes (Aleiodes) subcompressus sp. n., is close to $A$. (A.) angustatus (Papp) considering their common features: long second tergite, less broadening first tergite, less transverse head in dorsal view and testaceous ground colour of body; the distinction between the two species is keyed:

1 (2) Metasoma laterally not compressed, dorsally broadening posteriorly (Fig. 35). Hind femur thin, 6-7 times as long as broad distally (Fig. 36). Second tergite somewhat longer than broad basally (35:32) and broadening posteriorly. Third tergite transverse, clearly twice as broad basally as long medially, suture and its crenulation distinct between tergites 2-3 (Fig. 35). Eye in lateral view 1.6 times as high as wide and 1.5 to 1.3 times wider than gena (Fig. 37 see arrows). Head in dorsal view: eye slightly less large, temple less receded (Fig. 38). Antenna with 44-49 antennomeres. Pterostigma yellow. 9 : 7-7.2 mm. - Mongolia

Aleiodes (Aleiodes) angustatus (Papp, 1971)

2 (1) Metasoma postero-laterally weakly compressed, dorsally narrowing posteriorly (Fig. 34). Hind femur less thin, 3.8 times as long as broad medially (Fig. 33). Second tergite 1.3 times longer than broad behind and narrowing posteriorly. Third tergite as long as broad basally, suture missing between tergites 2-3 (Fig. 34). Eye in lateral view 1.7 times as high as wide and twice wider than gena (Fig. 32). Head in dorsal view: eye slightly larger, temple receded (Fig. 31). Antenna with 35 antennomeres. Pterostigma brownish with yellow basal third. $+: 4.8 \mathrm{~mm}$. - Korea

Aleiodes (Aleiodes) subcompressus sp. n.

The new secies is also close to $A$. (A.) pallidator (Thunberg) considering their common traits: receded temple in dorsal view (Figs 31, 43), posteriorly 
distinctly broadening first tergite (Figs 34, 42) and testaceous coloured body. Their distinctive features are as follows:

1 (2) Second tergite transverse, 1.3 times broader posteriorly than long, broadening backwards (Fig. 42). Metasoma not compressed laterally, broadening posteriorly (cf. Fig. 35). Gena in lateral view narrow: eye four times wider than gena (Fig. 39 see arrows). Head in dorsal view: eye large and 3.5 times longer than temple, temple straightly receded (Fig. 43). Hind femur broad, 3.5-3.6 times as long as broad (Fig. 44). Penultimate flagellomere 2.5-2.6 times as long as broad (Fig. 45). o. 4.5-6 mm. - Holarctic region Aleiodes (Aleiodes) pallidator (Thunberg, 1822)

2 (1) Second tergite long, 1.3 times longer than broad posteriorly, narrowing backwards (Fig. 34). Metasoma weakly compressed postero-laterally, narrowing posteriorly (Fig. 34). Gena in lateral view less narrow: eye twice wider than gena (Fig. 32 see arrows). Head in dorsal view: eye less large and 2.5 times longer than temple, temple rounded receded (Fig. 31). Hind femur less broad, 3.8 times as long as broad (Fig. 33). Penultimate flagellomere twice as long as broad (Fig. 41). $:$ : $4.5 \mathrm{~mm}$. - Korea

Aleiodes (Aleiodes) subcompressus sp. $n$.

\section{Cheloninae}

\section{Chelonus moczari sp. $\mathrm{n}$.}

(Figs 48, 52-58, 65-70)

Material examined (4 $q$ and $9 \hat{\sigma}$ specimens) - (1) Female holotype and one male paratype: Korea, Sang-san (san = mount), $10 \mathrm{~km}$ NE from Pyongyan, swept in grasses, 1 July 1977, O. Dely et A. Draskovits, loc. no. 332. (2) One female paratype: Korea, Pektu-san, environs Samzi-yan hotel, lake-shore, 10 July 1977, leg. O. Dely et Á. Draskovits, loc. no. 371. (3) Two females and one male paratypes: Korea, Pektu-san, environs Samzi-yan hotel, swept in grass in a wood, 18-20 VII 1977, leg. O. Dely et Á. Draskovits, loc. no. 374. (4) One male paratype: Korea, Ryang-gang (gang = province), Chann-Pay plateau, Samzi-yan, 1700 m, 24-25 July 1975, leg. J. Papp et A. Vojnits, loc. no. 289. (5) Two male paratypes: Korea, Pektu-san, 2-6 km N from Samzi-yan hotel, swept in grass, 18 July 1977, leg. O. Dely et Á. Draskovits, loc. no. 372. (6) One male paratype: Korea, Pektu-san, envitons Samzi-yan hotel, lake-shore, 19 July 1977, leg. O. Dely et Á, Draskovits, loc. no. 376. (7) One male paratype: Korea, Pektu-san, Mupo, brook Dehongdan, swept in grass, 20 July 1977, leg. O. Dely et Á. Draskovits, loc. no. 380. (8) One male paratype: Korea, Pektu-san, environs Samzi-yan hotel, wood, 18-20 July 1977, leg. O. Dely et Á. Draskovits, loc. no. 382. (9) One male paratype: Korea, Ryang-gang (gang = province), Taehong-dan, 1000 m, 29 June 1988, leg. O. Merkl et Gy. Szél, loc. no. 1361.

Types depository - Holotype and four female + nine male paratypes are deposited in the Hungarian Natural History Museum (Department of Zoology), Budapest, Hym. Typ. Nos 12276 (holotype) and 12277-12288 (paratypes). 
Etymology - The new species is dedicated to Dr. László Móczár (1914-2015), professor emeritus at the Szeged University, doyen of the Hungarian hymenopterists celebrating his 100th birthday in the year 2014 .

Description of the female holotype - Body $4 \mathrm{~mm}$ long. Antenna long, as long as head, mesosoma and two-thirds of carapace combined, with 28 antennomeres. First flagellomere three times and penultimate flagellomere twice as long as broad, flagellum distally attenuating. - Head in dorsal view transverse (Fig. 52), twice as broad as long, eye 1.7 times longer than temple, temple receded, occiput excavated. Ocelli small and round, OOL twice as long as POL. Clypeus 0.57 times as wide as face, 1.6 times as wide as high medially (Fig. 53). Cheek in frontal view rounded (Fig. 53). Malar space half as long as height of compound eye. Gena widening ventrally, 1.2 times wider than eye (Fig. 54 see arrows). Head above rugose, face rugo-rugulose, gena striate, clypeus finely-densely punctate.

Mesosoma in lateral view 1.4 times as long as high. Notaulix faintly distinct by crenulation. Pair of lateral spines of propodeum small and blunt (Fig. 55). Mesosoma roughly rugose to rugose, scutellum punctate. Hind femur 3.3 times as long as broad basally (Fig. 56). Inner spur of hind tibia half as long as basitarsus. Hind tibia and tarsus equal in length.

Fore wing somewhat shorter than body. Pterostigma less wide, 2.8 times as long as wide, issuing $r$ distally from its middle, $r 0.7$ times as long as width of pterostigma; $3-S R$ 1.4 times longer than $r$, SR1 S-form, 2.8 times as long as 3-SR and ending far before tip of wing, 1-R1 as long as pterostigma (Fig. 57 see arrows).

Carapace in dorsal view elongate, 2.1 times as long as broad posteriorly, weakly broadening backwards, pair of basal carinulae short (Fig. 66). Carapace in lateral view less high: 2.8 times as long as high posteriorly, apically rounded, ventrally slightly incurved (Fig. 65). Cavity of carapace in ventral view almost as long as carapace itself, i.e., apically weakly incurved (Fig. 48). Ovipositor sheath short.

Body black. Papi pale ochre. Carapace basally with a pair of whitish yellow maculae. Coxae black, apically yellow. Fore and middle legs yellow. Hind femur black, hind tibia + tarsus yellowish, tibia distally blackish, tarsus with blackish suffusion. Wings subhyaline or faintly brownish fumous. Pterostigma brown, veins proximo-distally yellow to light brownish.

Variable features of the three female paratypes - Body 3.5-3.7 mm long. Antenna with 27 (1 + ) and 28 (2 + ) antennomeres. Head in dorsal view 1.9-2 times as broad as long, eye 1.7 times $(1+)$ to twice $(2+)$ as long as temple. Gena in lateral view as wide as eye $(1+)$ to 1.1-1.2 times wider than eye, always broadening ventrally (cf. Fig. 54 see arrows). Hind femur $3.1(1+$ ) and 3.3 times ( 2 +) as long as broad (cf. Fig. 56). Fore wing: $3-S R$ slightly (1 + ) to 1.1-1.25 times ( 2 ) as long as $r$; metacarp 0.8 times ( 1 ) to as long as pterostigma (2 ㅇ) (cf. Fig. 57 see arrows). Carapace in dorsal view 1.9-2.1 times as long as broad posteriorly (cf. Fig. 66); in lateral view 2.5-2.9 times as long as high (cf. Fig. 65 see arrows). Pair of basal maculae on carapace small and darkening $(1$ O $)$.

Description of the nine male paratypes - Similar to the female types. Body 3-4.3, usually 3.3-3.5, mm long. Antenna about as long as body and with 27-33 antennomeres. Head in dorsal view 1.9 times $(2 \delta)$ as long as broad, temple receded, eye $1.2\left(2 \delta^{\lambda}\right)$ to 1.7 times $(7 \hat{\jmath})$ as long as temple (Fig. 58). Gena in lateral view as wide as eye. Mesosoma in lateral view $1.4(2 \hat{\jmath})$ to 1.6 times $(7 \hat{\jmath})$ as long as high (cf. Fig. 54 see arrows). Fore wing: $1-R 1$ variably 0.8 to 1.1 times as long as pterostigma (Figs 67-68 see arrows). Carapace in dorsal view elongate, more or less broadening posteriorly, 2.1 to 2.3 times longer than broad at 
rear (Fig. 69). Carapace in lateral view $2.9(7 \AA)$ to 3.2 times $(2 \hat{\jmath})$ as long as high posteriorly, apically sometimes less rounded (Fig. 70 see arrows). Basal pair of whitish yellow maculae less distinct $(3 \stackrel{3}{3})$.
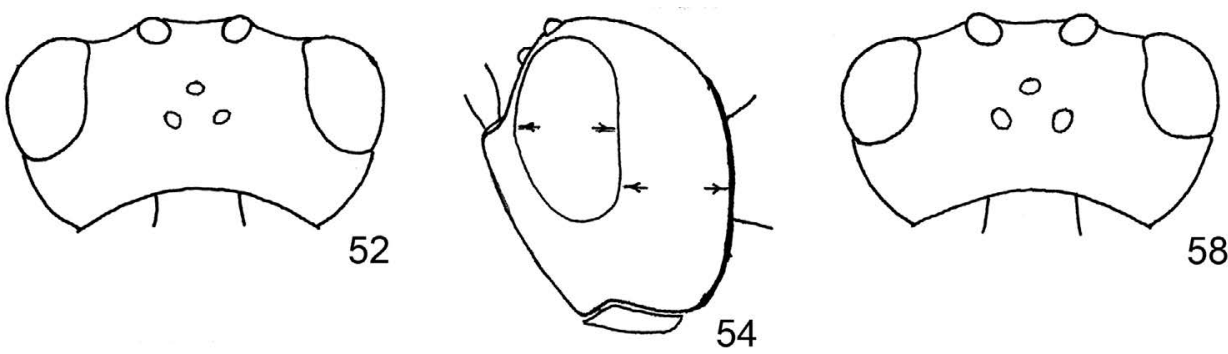

52

54
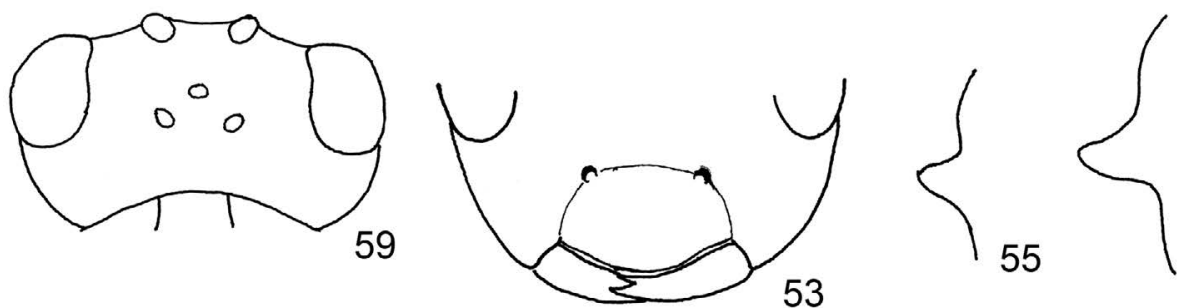

53
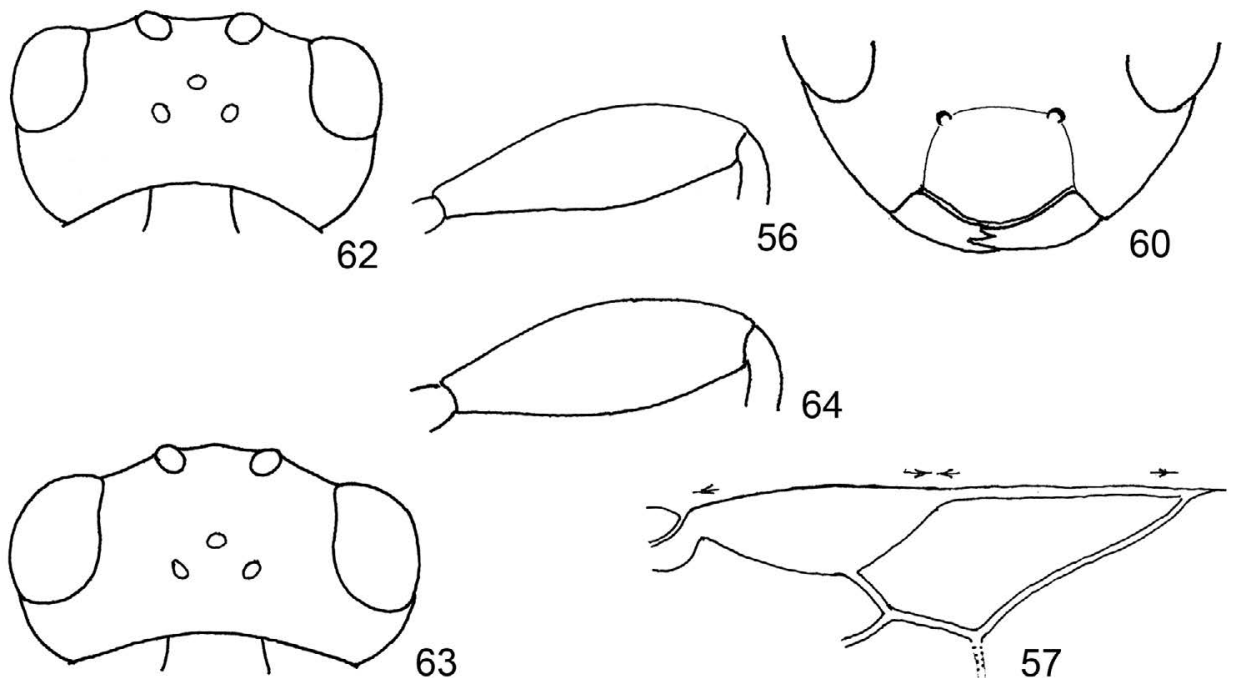

Figs 52-64. 52-58. Chelonus moczari sp. n. ( + holotype: 52, 54-57; $ð$ paratype: 53 and 58): $52=$ head in dorsal view, $53=$ lower half of head in frontal view, $54=$ head in lateral view, $55=$ spine of propodeum in lateral view , $56=$ hind femur, $57=$ distal part of right fore wing, 58 = head in dorsal view. $-59-60$. Chelonus corvulus Marshall ( $\left.+\delta^{\lambda}\right): 59=$ head in dorsal view, 60 = lower half of head in frontal view. $-61-62$. Chelonus asiaticus Telenga (ㅇ): $61=$ spine of propodeum in lateral view, $62=$ head in dorsal view. $-63-64$. Chelonus formosanus Sonan (+): 63 = head in dorsal view, 64 = hind femur 
Taxonomic position - The chelonine new species, Chelonus moczari sp. n., is close to Ch. corvulus Marshall and to Ch. asiaticus Telenga, i.e., the new species runs to these two species with Toвias' keys (1986: 307-317 and 2000: 461-480). The new species is distinguished separately from the two species indicated:

1.) Distinction between Ch. corvulus and Ch. moczari:

1 (2) Temple in dorsal view rounded (Fig. 59). Cheek in frontal view more rounded, 1.4 times as wide as high (Fig. 60). Antenna with 24-26 () and 27-29 $(\AA)$ antennomeres. Fore wing: pterostigma wide, 2.5-2.6 times as long as wide (Fig. 71 see arrows). Carapace latero-apically truncate, slightly more belly (Fig. 72 see arrows). Carapace entirely black. $+\mathcal{O}^{\lambda}: 4-6$ mm. - Palaearctic region

Ch. corvulus Marshall, 1885

2 (1) Temple in dorsal view receded (Figs 52,58). Cheek in frontal view rounded, clypeus 1.6 imes as wide as high (Fig. 53). Antenna with 27-28 (ㅇ) and 27-33 $\left({ }^{\lambda}\right)$ antennomeres. Fore wing: pterostigma less wide, 2.8(-2.7) times as long as wide (Figs 57, 67-68 see arrows). Carapace latero-apically rounded, slightly less belly (Figs 65, 70 see arrows). Carapace black, basaly with a pair of yellow maculae. $+\delta^{\lambda}: 3.5-4 \mathrm{~mm}$. - Korea

Chelonus moczari sp. $n$.

2.) Distinction between Ch. asiaticus and Ch. moczari:

1 (2) Carapace in lateral view high, 2.3-2.5 times as long as high posteriorly (Fig. 73-74 see arrows). Pair of lateral spines of propodeum strong (Fig. 61). Temple in dorsal view weakly rounded and almost as long as eye (Fig. 62). Fore wing: pterostigma issuing $r$ from its middle (or just distally) and wide, 2.6-2.5 times as long as wide (Fig. 49 see arrows). 우: (3-) 4-6 (-7) mm. - Palaearctic region Chelonus asiaticus Telenga, 1941

2 (1) Carapace in lateral view less high, 2.7-3.2 times as long as high posteriorly (Figs 65, 70). Pair of lateral spines of propodeum less strong (Fig. 55). Temple in dorsal view receded and $0.55-0.7$ times as long as eye (Figs $52,58)$. Fore wing: pterostigma issuing $r$ clearly distally from its middle (Figs 57, 67-68 see arrows). 우순 3.5-4 mm. - Korea

Chelonus moczari sp. n.

The new species runs also to Chelonus formosanus Sonan (Sonan 1932: 70) with CHEN and J's key (2002: 221-224) to the Chinese species of the genus Chelonus. The two species differ from each other by the key disclosed:

1 (2) Eye in dorsal view 2.1 times as long as temple, temple strongly receded (Fig. 63). Carapace in dorsal view stout, 1.6-1.7 times as long as broad (Fig. 76), in lateral view more curved and apically deeply rounded (Fig. 75 see arrows). Hind femur 2.9 times as long as broad (Fig. 64). Fore 
wing: pterostigma 2.5 times as long as wide, issuing $r$ from its middle, $r$ 1.5 times longer than 3-SR (Fig. 50). 우: $6 \mathrm{~mm}$. - Taiwan, China, India, Trinidad-Tobago, Barbados Chelonus formosanus Sonan, 1932
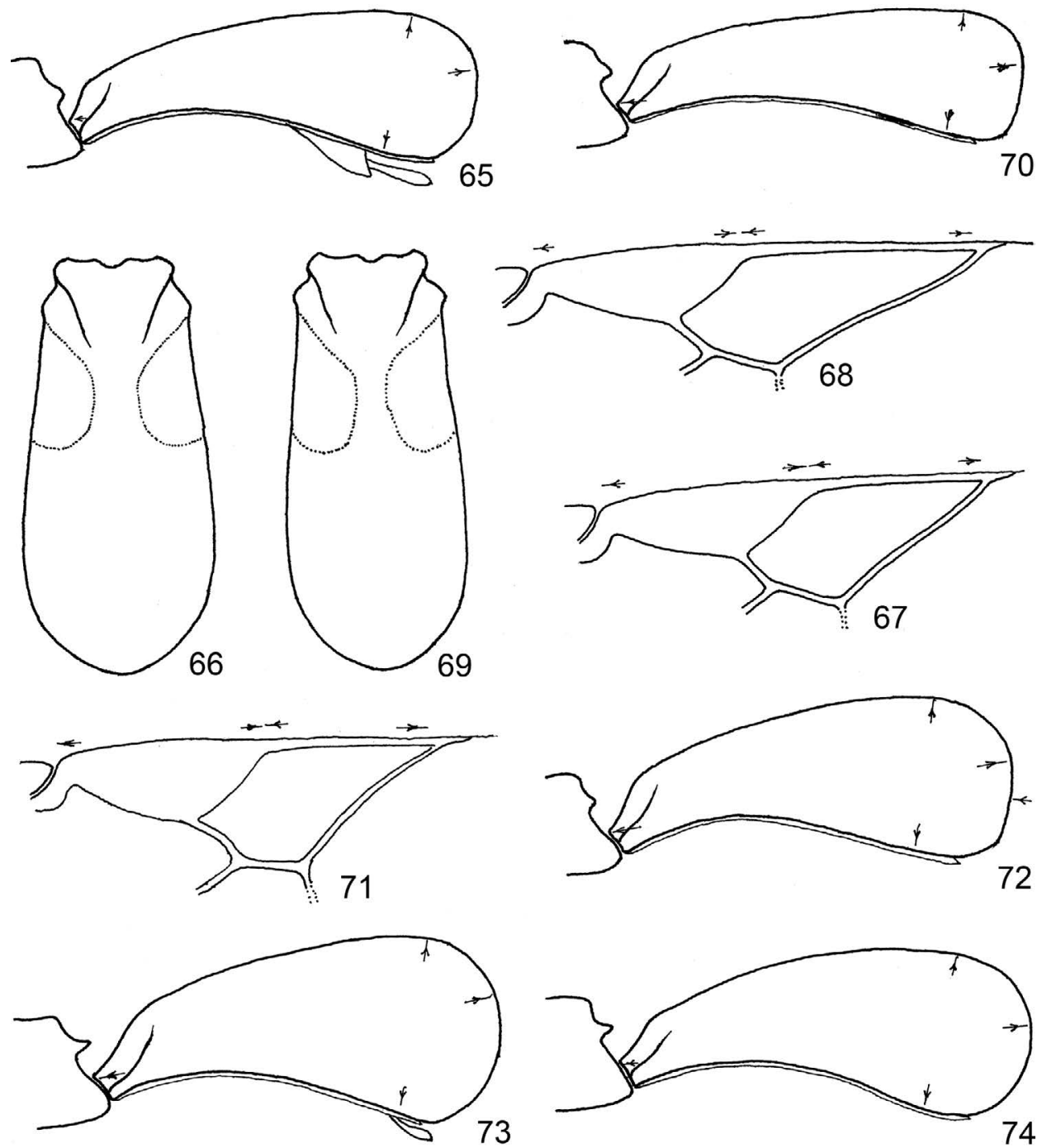

Figs 65-74. 65-70. Chelonus moczari sp. n. (ㅇ holotype: 65-66, § paratype: 65, 67-70): $65=$ carapace in lateral view, 66 = carapace in dorsal view , 67-68 = distal part of right fore wing, $69=$ carapace in dorsal view, $70=$ carapace in lateral view. $-71-72$. Chelonus corvulus Marshall $(+\overbrace{}^{\widehat{T}})$ : 71 = distal part of right fore wing, 72 = carapace in lateral view. $-73-74$. Chelonus asiaticus Telenga $(+\hat{\jmath}): 73(+)-74(\hat{\jmath})=$ carapace in lateral view 
2 (1) Eye in dorsal view 1.7-2 times as long as temple, temple receded (Fig. 52). Carapace in dorsal view elongate, 1.9-2.1 (ㅇ) and 2.1-2.3 ( $\overbrace{}^{\lambda})$ times as long as broad (Figs 66, 69). Carapace in lateral view less curved and apically rounded (Figs 65, 70). Hind femur 3.1-3.3 times as long as broad (Fig. 56). Fore wing: pterostigma 2.8-3.3 times as long as wide, issuing $r$ distally from its middle, $r$ shorter than 3-SR (Figs 57, 67-68). + ${ }^{\lambda}: 3.3-4.3$ mm. - Korea

Chelonus moczari sp. $\mathrm{n}$.

\section{BLACINAE \\ Blacus (Leioblacus) pentagonus sp. $\mathrm{n}$.}

(Figs 77-83)

Material examined - Female holotype: Korea, prov. Kangwon, Do Wonju, Mt. Chiak, taken with mercury vaour lamp at night, 3-4 August 1995, leg. D-S. Ku. Holotype is in good condition: (1) glued on card point by its mesosternum, (2) right middle tarsus hardly visible owing to the mounting.

Type depository - Holotype is deposited in the Hungarian Natural History Museum (Department of Zoology), Budapest, Hym. Typ. No. 12274.

Etymology - The new species received the name "pentagonus" after the form of the propodeal areolae (Fig. 79).

Description of the female holotype - Body $1.8 \mathrm{~mm}$ long, fore wing $1.9 \mathrm{~mm}$ long. Antenna as long as fore wing and with 19 antennomeres. First flagellomere 3.6 times as long as broad apically, second flagellomere distinctly shorter than first flagellomere: 2.4 times as long as broad, i.e., first flagellomere 1.5 times longer than second flagellomere (Fig. 77). Flagellomere 3-18 gradually shortening so that penultimate flagellomere 1.8 times as long as broad; ultimate flagellomere four times as long as broad and pointed apically.

Head in dorsal view of usual "Blacus-form": cubic, 1.5 times as broad as long, temple 1.2 times longer than eye, rounded, gena and occiput margined (Fig. 78). Eye in lateral view 1.6 times as high as wide, gena as wide as eye. Clypeus three times as wide as high, distance between tentorial pits twice longer than that between pit and eye.

Mesosoma in lateral view 1.3 times as long as high. Pronotum laterally striolaterugose, medially rugose. Notauli evenly deep, narrow, subcrenulate (or almost smooth), meeting and shortly continuing. Mesoscutal lobes glabrous and polished. Scutellum also polished and margined. Propodeum with four, pentagonal areolae, areola basalis short, pair of lateral tubercules missing, laterally from areolae propodeum rugulose (Fig. 79). Precoxal sulcus wide and faintly crenulate, otherwise mesopleuron polished (Fig. 80). Hind femur thin, 5.5 times as long as broad apically, weakly thickening distally (Fig. 81). Fore femur five times as long as broad. Claws without long blackish bristles.

Fore wing slightly longer than body $(1.9 \mathrm{~mm})$. Pterostigma 3.6 times as long as wide, width of pterostigma equal to length of $r(10: 10), 3-S R(+S R 1)$ almost straight (or faintly arched) and reaching tip of wing. Parastigma distinct, first discal cell acute anteriorly (Fig. 82 see arrow). Subdiscal (or brachial) cell nearly missing.

Metasoma about as long as mesosoma. First tergite 1.6 times as long as broad and gradually broadening posteriorly, pair of basal keels almost reaching hind end of tergite, tergite with rather longitudinal rugulosity; second tergite quadrate in form: slightly long- 

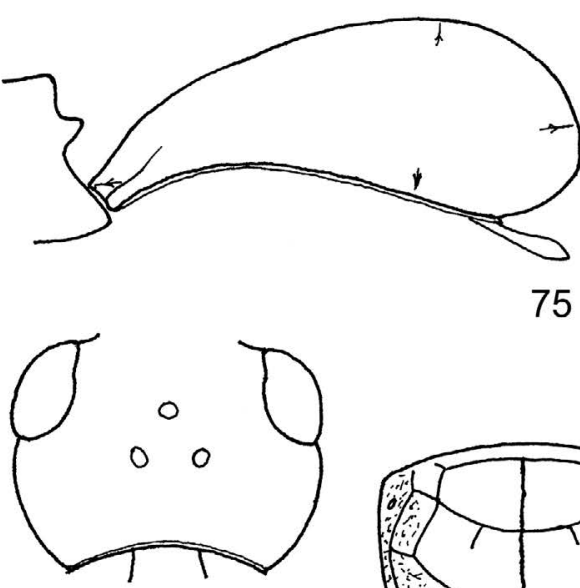

85
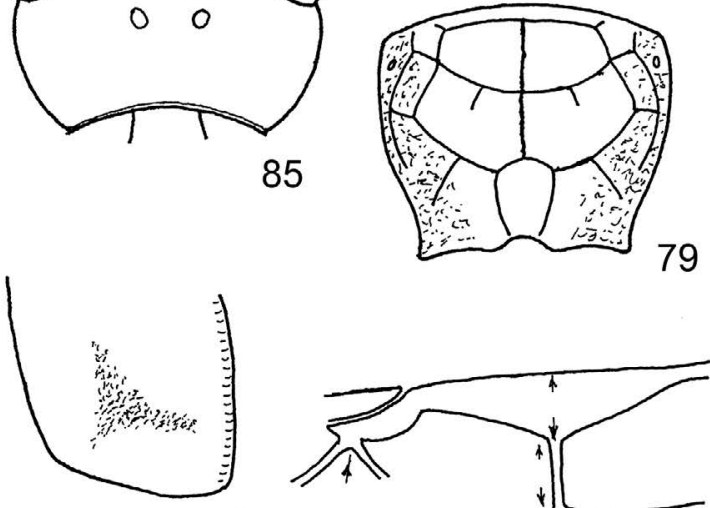

80

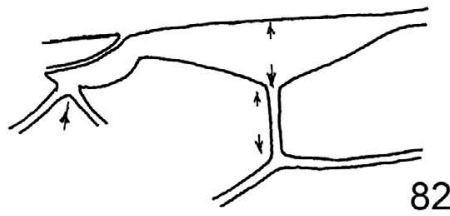

82
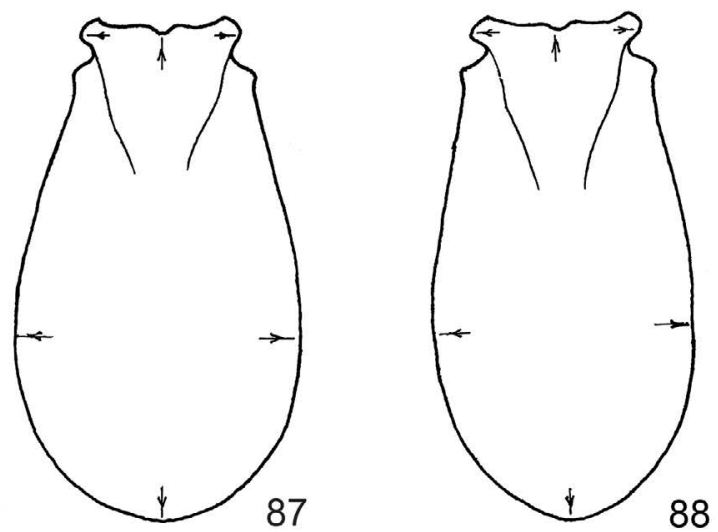

Figs 75-88. 75-76. Chelonus formosanus Sonan ( $(+)$ : 75 = carapace in lateral view, 76 = carapace in dorsal view. $-77-83$. Blacus (Leioblacus) pentagonus sp. $\mathrm{n}$. ( + holotype): $77=$ flagellomeres $1-2,78=$ head in dorsal view, 79 = propodeum, $80=$ mesopleuron with precoxal sulcus, $81=$ hind femur, $82=$ distal part of right fore wing, $83=$ tergites $1-2 .-84-86$. Blacus (Leioblacus) fischeri Haeselbarth (ㅇ): $84=$ tergites 1-2, $85=$ head in dorsal view, $86=$ flagellomeres 1-2. -87-88. Microchelonus koreanus Tobias $87($ ㅇ $)-88(\lesssim)=$ carapace in dorsal view 
er than broad behind (35:30, Fig. 83), together with further tergites polished. Ovipositor sheath somewhat shorter than hind tibia (32:38).

Ground colour of body brown. Scape, pedicel and flagellomeres 1-2(-3) yellow, rest of flagellomeres brownish. Face and pronotum light brownish. Tegula and legs yellow, fifth tarsomeres darkening. Wings hyaline, pterostigma yellow, veins proximo-distally pale yellow to yellow.

Male and host unknown.

Taxonomic position - The blacine new species, Blacus (Leioblacus) pentagonus sp. n., is close to Blacus (Leioblacus) fischeri Haeselbarth: it runs to this species with HaEselbarth's (1973) as well as with van ACHTERBERG's (1988) and BвцоковуLsкij's (2000) keys to the Palaearctic species of Blacus. The two species are distinguished by the features as follows:

1 (2) Areolation of propodeum as in Fig. 46. First tergite 2-2.3 times as long as broad posteriorly, parallel-sided; second tergite 1.5-1.6 times longer than broad posteriorly (Fig. 84). Fore wing: pterostigma somewhat less wide than length of $r, r$ issuing clearly distally from its middle (Fig. 47 see arrows). Head in dorsal view slightly more cubic, 1.4 times as broad as long, temple 1.3 times longer than eye (Fig. 85). Antenna with 17-18 antenomeres; first flagellomere slightly longer than second flagellomere (11:10, Fig. 86). + : 2.3 mm. - Germany, Nederland, Austria, Romania, Slovenia, Asiatic Russia: Primorski krai

Blacus (Leioblacus) fischeri Haeselbarth, 1973

2 (1) Areolation of propodeum as in Fig. 79. First tergite 1.6 times as long as broad and broadening posteriorly; second tergite slightly longer than broad posteriorly (35:30, Fig. 83). Fore wing: pterostigma somewhat wider than length of $r$ (10:9), $r$ issuing slightly distally from its middle (Fig. 82 see arrows). Head in dorsal view slightly less cubic, 1.5 times as broad as long, temple 1.2 times longer than eye (Fig. 85). Antenna with 19 antennomeres; first flagellomere long, 1.5 times longer than second flagellomere (Fig. 77). $\odot: 1.8$ mm. - Korea

Blacus (Leioblacus) pentagonus sp. n.

\section{FAUNISTIC LIST}

The localities are given in an abbreviated form, i.e., with the localitynumbers presented in the labels of the braconid specimens (and in the itinerary of the collecting trips). Below those locality-numbers with their detailed collecting data are listed which in the Faunistic List are itemized account.

The species new to the fauna of Korea are marked with an asterisk.

Where not indicated the distributional outlines are applied after $\mathrm{Yu}_{\mathrm{u}}$ et al. 2012. 
1.) List of the North Korean (Democratic People's Republic of Korea) and South Korean (Republic of Korea, no. 1627) localities by the collectors of the Hungarian Natural History Museum:

No. 19. Prov. South Phenan: Bong-ha ri, on the river Te-dong, about $45 \mathrm{~km}$ E of Pyongyang, 23 May 1970, netting on meadow and in shrubby undergrowth, leg. Mahunka et Steinmann.

No. 36. Prov. South Phenan: Pyongyang, Nung-ra do, island in the river Te-dong, 27 May 1970, singled and netted material, leg. Mahunka et Steinmann.

No. 188. Prov. South Pyongan: Pyongyan, Pyongyan Hotel garden, 18 August 1971, taken with Malaise trap, leg. Papp et Horvatovich.

No. 217. Prov. Ryang-gang: Mt. Pektus, 1900 m, 28 August 1971, singled material in clearings with Aconitum-flowers in Larix-Betula forest near upper forest level, leg. Papp et Horvatovich.,

No. 218. Prov. Ryang-gang: Chann-Pay plateau, Samzi-yan, 1600 m, 28 August 1971, taken with Malaise trap in Larix-Betula forest, leg. Papp et Horvatovich.

No. 231. Prov. South Pyongan: Zamo-san, 60 km NE from Pyongyan, 2 September 1971, netting in sweet chestnut (Castanea crenata) forest in nature conservation field, leg. Papp et Horvatovich.

No. 245. Kaesong: Mts Pakyon, Pakyon popo, 27 km NE from Kaesong, 8 September 1971, netting from bushes, shrubs and grasses in the environs of the waterfall, leg. Papp et Horvatovich.

No. 273. Prov. South Pyongan: Nam-po, 19 July 1975, netting the shrub level of a RobiniaCastanea wood, leg. Papp et Vojnits.

No. 281. Prov. Ryang-gang: Chann-Pay plateau, $24 \mathrm{~km}$ NW from Samzi-yan, along the road to Mt. Pektu, 2000 m, 24 July 1975, 10-13:30 h, netting in more or less devasted clearings of Larix-Betula forest, leg. Papp et Vojnits

No. 293. Prov. Ryang-gang: Hyesan, Mt. Ze-dong, 1150 m, 26 July 1975, 10-13:30 h, netted material at the edge of a Larix wood shrubby level, leg. Papp et Vojnits.

No. 305. Prov. Pyong-Sung: Beksung-li, Zamo-san, $60 \mathrm{~km}$ NE from Pyongyan, 1 August $1975,12-18 \mathrm{~h}$, at fore-noon rainy weather and $22-24^{\circ} \mathrm{C}$, after $13 \mathrm{o}^{\prime}$ clock cloudy weather with sunshine and $28-30^{\circ} \mathrm{C}$, netted material, early in the afternoon vegetation wet.

No. 315. Prov. Gang-von: district On-dzong, Kumgang-san, near Hotel Gosong, 250 m, 4 August $1975,20-0: 30 \mathrm{~h}, 26^{\circ} \mathrm{C}$, taken with mercury vapour lamp in a coniferous-locust tree wood, leg. Papp et Vojnits.

No. 332. De Sang-san, 10 km NE from Pyongyan, 1 July 1977, confined, rather stony area, coniferous wood mixed with Acer sp., leg. Dely et Draskovits.

No. 343. Tesson, water basin, about 35 km SW from Pyongyan, 4 July 1977, coniferous wood mixed with Robinia trees, swept material, leg. Dely et Draskovits.

No. 346. Sa Gam, water basin and inundation area of a river, about $30-40 \mathrm{~km} \mathrm{~N}$ from Pyongyan, 5 July 1977, mixed coniferous / Robinia wood, leg. Dely et Draskovits.

No. 347. Same locality and collecting as No. 346.

No. 354. Kumgang-san (= Diamond Mts), Hotel Kumgang-san at village Ontsong, 10 July 1977, taken with Malaise-trap standing in a clearing of a forest, leg. Dely et Draskovits.

No. 363. Kumgang-san (=Diamond Mts), 3-4 km S from Hotel Kumgang, 12 July 1977, netting in shrubby and grass vegetation at the edge of the growing forest ear waterfall, leg. Dely et Draskovits.

No. 369. Pektu-san: environs of Explosion Lake, 18 July 1977, netting in grass, about 2000$2500 \mathrm{~m}$, leg. Dely et Draskovits. 
No. 374. Pektu-san, wooden environs of the Samzi-yan hotel, 18 July 1977, netting in shrubby and grass vegetation about $16 \mathrm{~km}$ E from the hotel, leg. Dely et Draskovits.

No. 376. Same locality and collecting as No. 374.

No. 380. Pektu-san, Mupo, brook Dehongdan, 30 July 1977, netting in grass along the brook, leg. Dely et Draskovits.

No. 381. Pektu-san, half-way between Samzi-yan and Mupo, 30 July 1977, netting in shrubby and flowering vegetation, leg. Dely et Draskovits.

No. 488. Kangwon prov.: Kumgan-san, 12 October 1978, swept from Dryopteris-like fern species, a rather cold, windy day, leg. Vojnits et Zombori.

No. 525. South Pyongan prov.: Lake Taesong-ho, 13 September 1979, singled and netted in ruderals, leg. Steinmann et Vásárhelyi.

No. 871. Pyongyang City: Hotel Pyongyan, 28 July 1982, singled material collected around lampshades in the garden of the hotel, leg. Forró et Ronkay.

No. 911. Pyongyang City: Daesong-san, 15 May 1985, warm sunny afternoon with wind, swept the underwood and shrubs, leg. Vojnits et Zombori.

No. 917. Same locality and collecting as No. 911, 16 May 1985, leg. Vojnits et Zombori

No. 923. Pyongyang City: Daesong-san, 17 May 1985, night collecting at blended light (250

W) by using Honda generator, from $20 \mathrm{~h}$ till $22 \mathrm{~h}$, leg. Vojnits et Zombori.

No. 930. North Pyongan prov.: Myohyang-san, 21 May 1985, blue sky with some white clouds, warm afternoon. Swept along road-side by the River Hyangsan-chon, leg. Vojnits et Zombori.

No. 944. South Pyongyan prov.: Lokam Reserve (some $40 \mathrm{~km}$ north of the capital), 25 May 1985 , cool afternoon with high wind, temperature about $18^{\circ} \mathrm{C}$, swept material from mixed vegetation, leg. Vojnits et Zombori.

No. 952. Kangwon prov.: Kumgang-san, 27 May 1985, cool afternoon with overcast sky, temperature about $17^{\circ} \mathrm{C}$, swept the undergrowth of a mixed forest around the rest house Oe-Kumgang, leg. Vojnits et Zombori.

No. 961. Pyongyang City, Botonggang Park, 30 May 1985, warm suffy forenoon, temperature about $24^{\circ} \mathrm{C}$, swept in much degraded vegetation, leg. Vojnits et Zombori.

No. 969. Pyongyang City: Daesong-san, 31 May 1985, cool, windy evening with bright moon, night collecting at blended light $(250 \mathrm{~W})$ fed by Honda generator, leg. Vojnits et Zombori.

No. 999. Ryanggang prov.: Samzi-yon, 5 June 1985, warm and sunny forenoon, temperature about $24^{\circ} \mathrm{C}$, sweeping in a Larix-Betula forest on the way to Pektu-san, leg. Vojnits et Zombori.

No. 1000. Same locality and collecting as No. 999.

No. 1050. South Hwanghae prov.: Haeju, Suyong-san, 16 October 1987, deciduous forest of the SE slope, leg. Korsós et Ronkay.

No. 1331. Kangwon prov.: Kumgang-san, Onjong-ri, 20 June 1988, cloudy forenoon, Pinus densiflora forest, swept from vegetation, leg. Merkl et Szél.

No. 1336. Kangwon prov.: Kumgang-san, Onjong-ri, 21 June 1988, warm sunny forenoon, a little degragaded vegetation along concrete roads in Pinus densiflora forest, singling and sweeping, leg. Merkl et Szél.

No. 1345. Ryanggang prov.: Samzi-yon, 26 June 1988, warm sunny day, Larix olgensis forest mixed with Picea coreana, P. ajanensis and Betula pendula, with reach shrub-level and underwood, singling and swept, leg. Merkl et Szél.

No. 1353. Ryanggang prov.: Pektu-san, 1500 m, 27 June 1988, cloudy warm afternoon, dark and dense largely untouched Larix olgensis forest mixed with many Betula pendula, rich underwod along a booklet, singling and swept, leg. Merkl et Szél. 
No. 1355. Ryanggang prov.: NW from Samji-yon, 31 km on Pektu-san road, $2000 \mathrm{~m}, 28$ June 1988, cloudy, cool day, Larix olgensis forest with rather poor underwood, near to the tree-borderline, singled and swept, leg. Merkl et Szél.

No. 1361. Ryanggang prov.: Taehong-dan, 1000 m, 29 June 1988, cloudy warm afternoon, young Larix olgensis-Betula pendula forest, singling and swept mainly from flowering shrubs, leg. Merkl et Szél.

No. 1381. Pyongyang City: Ryongak-san, 22 May 1991, swept insects from a rocky forest and a brook valley, leg. Ronkay et Vojnits.

No. 1410. North Pyongan prov.: Myohyang-san, 27 May 1991, singled insects at light in the Hyang-san valley near to the Hwajangam cloister, leg. Ronkay et Vojnits.

No. 1627. Cheju prov.: Cheju-do (do=island), Halla-san, Halla-san National Park, $1280 \mathrm{~m}$, 22 August 1992, taken at night on illuminated white screen in a forest clearing 20:3023:30 h, leg. Ronkay et Vojnits.

2.) List of the South Korean (Republic of Korea) localities by the entomologist Deok-Seo Ku (see also Papp 2007: 2):

Ku-7. Chungbuk, Chungju Sanchok, Yongdong, 23 May 1993.

Ku-10. Chungnam, Kum-san Chubu, Kaedoksa, 22 May 1993.

Ku-13. Chungnam, GyeongNam, Chinju City, Chojeon-dong, taken at night with lamp July-September 1993 and July 1995.

Ku-15. Jeonnam Kwangyang, Okryong Dongbok, Paikun Mt., taken with UV lamp, 14 May 1994.

Ku-16. Kangwon, Chunchon Shinbuk, Chochon 5-ri, 25 May 1993.

Ku-17. Kangwon, Chunchon Shinbuk, Soyangdaem, 25 May 1993.

Ku-18. Kangwon, Inje Inje Hakang, 27 May 1993.

Ku-22. Kangwon, Kosong Kansong, Kongbongsa, 26 May 1993.

Ku-41. Kyonggi, Suwon, Mt. Yogi, 29 April-July 1994, taken with Malaise trap.

Ku-43. Kyonggi, Yanggu Duta, 30 May 1992.

Ku-46. Kangwon-do, Wonju, Mt. Chiak, taken with Mercury vapour lamp, 3-4 July 1995.

3.) List of the North Korean (Democratic People's Republic of Korea) localities by the Bulgarian entomologists P. Beron and A. Popov (see also PAPP 1990a: 90-91 and 1990b: 321):

B / P-1. Pyongyan City, 8 August 1982.

B / P-11. North Pyongyan prov.: Myohyang-san, 14 August 1982.

B / P-12. Kangwon prov.: Kumgang-san, environs of the Hotel, 20 August 1982.

\section{Blacinae}

Blacus (Leioblacus) pentagonus sp. n. - Described in this paper.

\section{Brachistinae}

${ }^{*}$ Eubazus micropilosus Belokobylskij, 1998 - 1 q (as E. flavipes Haliday in PAPP 1989a: 82, emendation): No. 218.

Schizoprymnus temporalis Tobias, $1966-1 \delta^{\lambda}$ : No. 36. First reported from Korea by PAPP (1989a: 82). 
Schizoprymnus tuberosus Telenga, $1941-1$ \%: No. 1345. Widely distributed in the eastern Palaearctic Region, nearest to Korea reported from Asiatic Russia (Primorski krai).

\section{Braconinae}

Bracon (Ophthalmobracon) acunens sp. n. - Described in this paper.

Bracon (Glabrobracon) bitumor sp. n. - Described in this paper.

*Bracon (Glabrobracon) claripennis Thomson, $1894-1$ ㅇ: No. 381.1 §̊: B / P-11.

*Bracon (Glabrobracon) discoideus Wesmael, 1838 - 1 o : Onpho, ad. Chongjin, $17 \mathrm{Au}-$ gust 1959, leg. Pisarski et Preszyński. - The female specimen represents an albanic form: mesosoma reddish yellow, three spots of mesoscutum and almost entire propodeum faintly brownish. In Europe frequent.

Bracon (Glabrobracon) epitriptus Marshall, 1885 - 1 ㅇ: No. 231.1 ठ̊: Ku-13. 1 ठ̊: Ku-41. 2 o : Ku-43. - Frequent to common in the Palaearctic Region.

${ }^{*}$ Bracon (Bracon) flavipes Nees, $1834-1$ 9 : North Pyongyan prov.: Musan, 19-20 August 1991, leg. Han Eng Hi, 1 O: 1705. - In Europe sporadic, reported from Mongolia.

Bracon (Glabrobracon) fuscicoxis Wesmael, 1838 - 1 q: No. 376, 1 \%: No. 917. - Widely distributed in Europe, reported from Asiatic Turkey, Asiatic Russia (Irkutsk) and Korea (Papp 1996: 154, 2012: 31; Tobias 2000: 162).

Bracon (Glabrobracon) immutator Nees, $1834-1$ o: 1720, 1 q: 1747. - The species Bracon (Bracon) yasudai Maetô et Uesato, 2007 (Japan) seems very near to B. immutator var. hemirugosus (Szépligeti) (its tergites 2-4 weakly sculptured; PApp 2012: 127-133). Frequent to common in the Palaearctic Region.

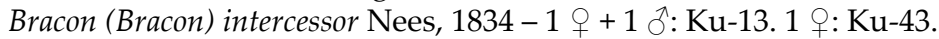

Bracon (Bracon) intercessor var. fallaciosus (Szépligeti, 1901) - 1 ठ̊: No. 488.

Bracon (Bracon) intercessor var. fulvus (Szépligeti, 1901) - 1 q: Ku-16.

Bracon (Bracon) intercessor var. laetus (Wesmael, 1838) -1 q +1 § : Ku-13.

Bracon (Glabrobracon) isomera Cushman, 1931 - 1 ㅇ: No. 188, 1 ㅇ: No. 245, 1 ð̊: No.

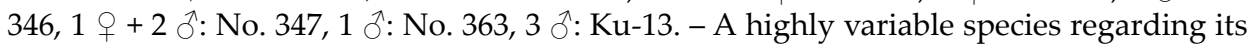

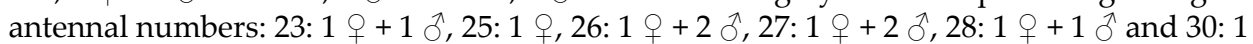
$\hat{0}$; corporal colour varies from (entirely) yellow to brownish yellow / brownish head and mesosoma. Reported from Korea (PApp 1996: 154).

*Bracon (Lucobracon) kasachstanicus Tobias, 1959 - 1 đ̊: No. 911. - So far known only in Kazakhstan.

Bracon (Lucobracon) larvicida Wesmael, 1838 - 1 क: Dephun, ad Kujang-dong, 6 IX 1959, leg. B. Pisarski. - In Europe frequent, in the eastern Palaearctic Region reported from Kazakhstan and Mongolia.

*Bracon (Orientobracon) leleji Tobias, 2000 - 1 q: No. 305. 1 đ̊: No. 952. - Described and so far known in Asiatic Russia (Kuril Islands, Sakhalin) and Japan (Honshu, Kyushu).

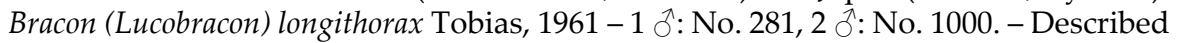
and reported from Asiatic Russia (Krasnoyarsk krai, Chita oblast) and Mongolia.

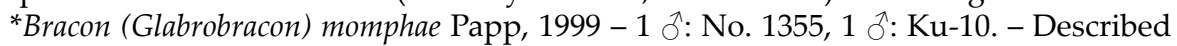
from England, reported from Scotland and Denmark.

*Bracon (Bracon) nigratus Wesmael, 1838 - 1 옹 No. 305. -Sporadic to frequent in the Palaearctic Region. Nearest to Korea known in Asiatic Russia: Primorye krai (ToвIAs \& Belokobylskij 2000: 135).

Bracon (Glabobracon) obscurator Nees, 1812 - 1 ㅇ: No. 381. 


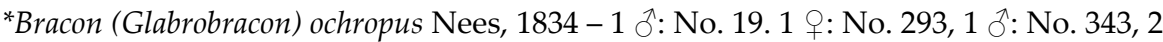
ô: No. 347, 1 q : 369, 1 ô: No. 944, 1 ô: No. 961. - Sporadic in the western Palaearctic Region: distributed in Germany (type locality), Hungary, Italy, Croatia and Serbia (Yu et al. 2012).

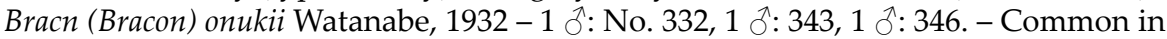
China, known in Japan and Vietnam; reported from Korea (КIM 1970, PApp 1996).

*Bracon (Glabrobracon) pachyceri Quintaret, 1912 - 1 Jै: No. 999. - Described from France (Provence), reported from several countries : Sweden, Czech Republic, Hungary, Bulgaria and Turkey.

Bracon (Glabrobracon) patens Papp, 1998 - 1 đ: Ku-13. - Described from and sofar known only in Korea.

Bracon (Glabrobracon) picticornis var. versicolor (Szépligeti, 1901) - 1 q: No. 293, 1 ปี: Ku-7. - Both the female and male specimens represent the albanic from (var. versicolor) of the species. Widely distributed in the Palaearctic Region.

Bracon (Bracon) scaricatus Papp, $1965-3$ o : No. 19, 1 ô: No. 930. - The three males from No. 19 represent an albanic form: ground colour of mesosoma reddish yellow with brownish to light brownish pattern (nominate form: mesosoma black). Described from Hungary, this is its second distributional data.

*Bracon (Lucobracon) shestakoviellus Tobias, 1957 - 1 o: Dephun, ad Kujang-dong, 6 IX 1959, leg. B. Pisarski. - Described from Kazakhstan (Tовіаs 1957: 493), reported from Turkey (Beyarslan et al. 2008: 1348) and European Russia (SAmartsev 2013: 326).

*Bracon (Bracon) speerschneideri Schmiedeknecht, 1897 - 2 \%: No. 343, 1 O : No. 374. - Distributed in Europe: England, France, Germany (type locality), Switzerland, Austria, Norway and Hungary.

*Bracon (Lucobracon) sphaerocephalus Szépligeti, 1901 - 1 ㅇ: No. 343. - In Europe frequent to common, in the eastern Palaearctic Region known in Mongolia and Asiatic Russia (Primorski krai).

*Bracon (Glabrobracon) titubans Wesmael, 1838 - 4 + (3 9 in Warszawa, Zoological Institute, 1 q in Budapest): Dephun, ad Kujang-dong, 4 IX 1959, leg. B. Pisarski. - In Europe widely distributed and frequent - in the eastern Palaearctic Region known in Mongolia (PApp 1971: 354).

*Bracon (Bracon) ussuricus Tobias, $2000-1 q+1$ § : Ku-22. - Described from Asiatic Russia (Primorski krai, South Sakhalin) and Japan (Honshu Island).

Bracon (Glabrobracon) variator var. flavipes Papp, 1966 - 1 o : B / P-12.

Bracon (Sculptobracon) yakui Watanabe, 1937 (= Br. burjaticus Tobias, 1961) -1 o : No. 374, 1 ठ : No. 525, Ku-15, Ku-46, B / P-1. - Distributed in the east Palaearctic Region: Japan, Korea, Asiatic Russia (Buryatskaya Respublika, Primorye krai).

${ }^{*}$ Ectemnoplax peruliventris Enderlein, 1920 - 1 o: 1752. - An east Palaearctic / North Oriental species: known in Taiwan (locus typicus), China, Japan (TовіAs \& BeloковуLsкij 2000: 168).

Euurobracon yokohamae (Dalla Torre, 1898$)$ (=Bracon penetrator Smith, $1877 ;=$ Exobracon montivagus Cameron, 1910) - 7 o : No. 1381. - An east Palaearctic / Oriental species: described from Japan, reported from Korea, China, Laos, Thailand, India (Товıаs \& BeloкоBYLSKIJ 2000: 191).

*Habrobracon concolorans (Marshall, 1900) - 1 q (as H. viktorovi Tobias in PApP 1996: 155 present emendation; Br. (H.) nigricans Szépl. det. Tobias 2000): No. 363. - Frequent to common in the Palaearctic Region.

*Habrobracon vernalis Szépligeti, 1911 - 1 \& (in Warszawa, Zoological Institute): Pyongyang, 21 VII 1959, leg. B. Pisarski et J. Prószyński. - In the eastern Palaearctic Region known in Tajikistan, Mongolia nd China; known also in Europe. 
*Iphiaulax (Euglyptobracon) impeditor (Kokujev, 1898) - 1 ㅇ (in Warszawa, Zoological Institute): Pyongyang, 21 VII 1959, leg. B. Pisarski et Prósziński. - Widely distributed in the Palaearctic Region, nearest to Korea known in Asiatic Russia (Krasnoyarski krai) and Kazakhstan (Yu et al. 2012).

\section{Cheloninae}

${ }^{*}$ Chelonus annularius Tobias, 2000 - 1 \%: No. 376. - Described from Asiatic Russia: Primorski krai (ТовіAs 2000: 469), the Korean locality is its second distributional data.

${ }^{*}$ Chelonus flavens Tobias, $2000-1 \delta$ : No. 305. - Described on the basis 33 \& and 4 o specimens from Asiatic Russia: Primorski krai (Товıаs 2000: 469), the Korean locality is its second distributional date.

Chelonus fumarius Tobias, 2000 - 1 : North Hamgyong prov.: Musan, 20 VIII 1991, leg. Han Eng Hi. - Described from and so far known only in Korea.

${ }^{*}$ Chelonus humilis Thomson, $1874-1$ ठ̊: 1361 . - In Europe widely distributed, known in Asiatic Russia: Krasnoyarsk.

Chelonus moczari sp. n. - Described in this paper.

${ }^{*}$ Chelonus productus Herrich-Schäffer, $1838-1$ §̊: North Pyongan prov.: Musea, 20 VIII 1991, leg. Han Eng. Hi. - In Europe widely distributed albeit not frequent; in Palaearctic Asia not reported so far.

${ }^{*}$ Chelonus scabrator (Fabricius, 1793) - 1 q: Ryang prov.: Paegam, 14 VI 1990, leg. Han Eng Hi. - Frequent in the Palaearctic Region, nearest to Korea known in Asiatic Russia (in several localities, Tobias 2000: 470).

Microchelonus contractus (Nees, 1816) - 1 : No. 281, 1 o: No. 380. - Frequent in the Palaearctic Region, known in Korea (PApr 2003: 124).

Microchelonus koreanus Tobias, 2000, ô new (Figs 51, 87-88) - 1 q: No. 354, 1 đ̊: No. 1336. - Described recently on the basis of the female holotype by Tobias (2000: 518); twelve years earlier this specimen was published under the name Ch. fenestratus (Nees) (Papp 1989b: 298). The male is similar to the female, the differences between them are as follows:

o holotype: Antenna with 16 antennomeres, first flagellomere 3.5 times and penultimate flagellomere 2.2 times as long as broad. Carapace in dorsal view just more broadening posteriorly, 1.8 times as long as broad, apically rounded, basally slightly less wide than that of the male (25:28) (Fig. 87). Carapace apically without foramen. Carapace basally yellow.

$\delta$ : Antenna with 22 antennomeres, first flagellomere 3.6 times and penultimate flagellomere 2.3 times as long as broad. Carapace in dorsal view just less broadening posteriorly, 1.9 times as long as broad, apically slightly more rounded, basally slightly wider than that (28:25) (Fig. 88). Carapace apically with a foramen: nearly round, i.e., weakly elliptic, 1.2 times as wide as high (Fig. 51). Carapace black, its basal fourth faintly yellow.

Microchelonus plenus Papp, 1989 - 1 : No. 1331. - Described from and up to now known only in Korea.

\section{Doryctinae}

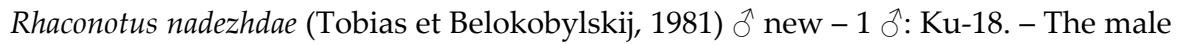
is deviating from the female in a few respects: (1) Head in dorsal view 1.6 times as broad as long, eye 1.2 times as long as temple ( +1.5 times); (2) Fore wing: pterostigma issuing $r$ 
distally from its middle ( $\circ$ from its middle); (3) First tergite twice longer than broad at rear ( : 1.5 times), weakly broadening posteriorly; (4) Body black, tergites very faintly rusty tinted (o: body with light colour pattern); (5) Body $3.5 \mathrm{~mm}$ long ( $+3.3 \mathrm{~mm}$ ). See also the original description by ToвiAs and BELOKовYLSKIJ (1981).

\section{Euphorinae}

*Ancylocentrus rufithorax (Telenga, 1950) - 1 + (Centistes collaris Thomson det. Belokobylskij 2000): B / P-11. - Described from Ukraine, reported from European Russia, Finland and Germany.

Centistes cuspidatus (Haliday, 1833) - 1 o: Ku-17. - Widely distributed and fairly frequent in the Palaearctic Region, known in Korea too (Ku et al. 2001: 104).

*Leiophron (Leiophron) ruficephala Chen et Achterberg, 1997 - 1 ' ${ }^{\top}$ : No. 1331. - Described from China (Yunnan), the Korean locality is its second distributional data.

Streblocera (Eutanycerus) macroscapus (Ruthe, 1856) - 1 + : No. 217. - A Palaearctic species albeit sporadically distributed.

\section{Exothecinae}

Acrisis brevicornis Hellén, 1957 (=A. koponeni Tobias, 1983) - 1 §̊: No. 374. - Known sporadically in the Palaearctic Region: Spain, Finland, Hungary, Russia, Iran, Korea.

\section{Hormiinae}

Hormius orientalis Belokobylskij, 1980 - 1 ㅇ: Ku-13. - First reported from Korea by PAPP (1987: 159); known in Asiatic Russia and Vietnam.

\section{Macrocentrinae}

Macrocentrus thoracicus (Nees, 1811) - 1 §o: 1050. - Widely distributed and fairly frequent in the Palaearctic Region.

\section{Meteorinae}

Meteorus graciliventris Musebeck, $1954-2$ ऽ̊: 273. - Described from Japan, reported from Asiatic Russia (Kamchatka, Magadan, Primorski krai), China and Korea.

Meteorus rubens (Nees, 1811) - 1 § : No. 871. - A cosmopolitan Meteorus species.

\section{Orgilinae}

Kerorgilus zonator (Szépligeti, 1896) - 3 q: No. 1353. - Originally the species was described from Hungary by Szépligeti in the genus Orgilus (SzÉPLigetr 1896: 241); new combination by van Achterberg (1985). The species is widely distributed in China, known in Korea. 


\section{Rhyssalinae}

Lysitermoides compsolechiae (Watanabe, 1970) (=Oncophanes striatus Belokobylskij) - 1 + (det. Belokobylskij 2011; Clinocentrus gracilipes Thomson det. Papp 1991): No. 944. - The genus Lysitermoides was described by van ACHTERBERg (1995) based on two species: L. huggerti van Achterberg and L. transversus van Achterberg taken in the USA (Maryland and Florida, respectively). The species L. compsolechiae was described from Japan originally in the genus Oncophanes (Watanabe 1970: 124). Reported from Korea and Asiatic Russia: Far East by BеLоковчLSKIJ (2004: 113, in key).

\section{Rogadinae}

*Aleiodes (Aleiodes) procerus Wesmael, $1838-1$ ô: No. 1627. - The male represents a melanic form: propodeum and metasoma black, fore pair of legs blackish brown, middle and hind pair of legs black. The nominate form has entirely light brown legs. Frequent to sporadic in the Palaearctic Region, nearest Korea known in Asiatic Russia (Primoski krai, Sakhalin).

Aleiodes (Aleiodes) subcompressus sp. n. - Described in this paper.

Aleiodes (Aleiodes) vittiger Wesmael, $1838-1$ ' $:$ No. 315. - Widely distributed and frequent to common in the Palaearctic Region.

Petalodes compressor (Herrich-Schäffer, 1838) (=P. unicolor Wesmael, 1838) -2 + : No. 923, 1 ㅇ: No. 969, 1 ㅇ: No. 1410. - Widely distributed in the Palaearctic Region; known in Korea and in Asiatic Russia (Primorski krai).

\section{REFERENCES}

Achterberg, C. van (1985): Kerorgilus gen. nov., a new genus of the Orgilinae (Hym., Braconidae) from the Palaearctic region. - Zoologische Mededelingen Leiden 59: 163-167.

Achterberg, C. van (1988): Revision of the subfamily Blacinae Foerster (Hymenoptera, Braconidae). - Zoologische Verhandelingen Leiden 249: 1-324.

Achterberg, C. van (1993): Illustrated key to the subfamilies of the Braconidae (Hymenoptera: Ichneumonoidea). - Zoologische Verhandelingen Leiden 283: 1-189.

Achterberg, C. van (1995): Generic revision of the subfamily Betylobraconinae (Hymenoptera: Braconidae) and other groups with modified fore tarsus. - Zoologische Verhandelingen Leiden 298: 1-242.

BeцоковүцsкiJ, S. A. (2000): Tribe Blacini. Pp. 226-244. In: Key to the Insects of Russian Far East. Vol. IV. Neuropteroidea, Mecoptera, Hymenoptera. Pars 4. -Vladivostok: Dal'nauka, pp. 651. [In Russian]

BeLоковуLSKIJ, S. A. (2004): Taxonomic reclassification of the East Asian species of the genus Oncophanes Förster (Hymenoptera: Braconidae, Rhyssalinae). - Proceedings of the Russian Entomological Society St. Petersburg 75(1): 106-117.

Beyarslan, A., Aydogdu, M. \& ErdoĞan, Ö. C. (2008): The subfamily Braconinae in Northern Turkey, with new records of Bracon species for the Western Palaearctic (Hymenoptera: Braconidae). - Linzer biologische Beiträge 40(2): 1341-1361.

Chen Jiahua \& Ji Qinge (2002): Systematic Studies on Cheloninae of China (Hymenoptera: Braconidae). - Fujian Science and Technology Publishing House, pp. 328. [in Chinese, English summary: key and descriptions of the new species, pp. 217-256.] 
EADY, R. D. (1968): Some illustrations of microsculpture in the Hymenoptera. - Proceedings of the Royal Entomological Society of London (A) 43(4-6): 66-72. https://doi. org/10.1111/j.1365-3032.1968.tb01029.x

Harris, R. A. (1979): A glossary of surface sculpturing. - Occasional Papers in Entomology (State of California, Department of Food and Agriculture) 28: 1-31.

Gauld, I. D. \& Bolton, B. (eds) (1988): 5. The structure of Hymenoptera. Pp. 58-86. In: The Hymenoptera. - British Museum (Natural History), Oxford University Press, 332 pp.

Haeselbarth, E. (1973): Die Blacus-Arten Europas und Zentral-Asiens (Hymenoptera, Braconidae). - - Veröffentlichungen der Zoologischen Staatssammlung München 16: 69-164.

KIm, C. W. (1970): Family 12. Braconidae Kirby (1837). Illustrated Encyclopedia of Fauna and Flora of Korea 11 (Insecta III): 215-241.

Ku, D. S., Beloковylskij, S. A. \& ChA, J. Y. (2001): Economic Insects of Korea 16, Hymenoptera (Braconidae). - Insecta Koreana Suppl. 23: 1-281.

PAPP, J. (1971): Ergebnisse der zoologischen Forschungen von Dr. Z. Kaszab in der Mongolei, 265. Baconidae (Hymenoptera). - Annales historico-naturales Musei nationalis hungarici (Pars zoologica) 63: 307-363.

PAPp, J. (1989a): Braconidae (Hymenoptera) from Korea, X. - Acta Zoologica Hungarica 35(1-2): 81-103.

PApp, J. (1989b): Braconidae (Hymenoptera) from Korea, XI. - Acta Zoologica Hungarica 35(3-4): 295-326.

PAPp, J. (1990a): Braconidae (Hymenoptera) from Korea, XII. (Microgastrinae). - Acta Zoologica Hungarica 36(1-2): 87-119.

PApp, J. (1990b): Braconidae (Hymenoptera) from Korea, XIII. (Meteorinae). - Acta Zoologica Hungarica 36(3-4): 319-330.

PAPP, J. (1996): Braconidae (Hymenoptera) from Korea, XVIII. Alysiinae, Braconinae. - Annales historico-naturales Musei nationalis hungarici 88: 145-170.

PApP, J. (2003): Braconidae (Hymenoptera) from Korea, XXI. Species of fifteen subfamilies. - Acta Zoologica Academiae Scientiarum Hungaricae 49(2): 115-152.

PApp, J. (2007): Braconidae (Hymenoptera) from Korea XXII. Subfamily Alysiinae. - Acta Zoologica Academiae Scientiarum Hungaricae 53(1): 1-38.

Papp, J. (2012): A revision of the Bracon Fabricius species in Wesmael's Collection deposited in Brussels (Hymenoptera: Braconidae: Braconinae). - European Journal of Taxonomy 21: 1-154.

SAmARTSEv, K. G. (2013): On the rare species of cyclostome braconid wasps (Hymenoptera: Braconidae) from Middle and Lower Volga territories of Russia. - Caucasian Entomological Bulletin 9(2): 315-328.

SonAN, J. (1932): Notes on some Braconidae and Ichneumonidae from Formosa, with description of 18 new species. - Transactions of the Natural History Society of Formosa 22: 66-87.

SzÉPLIGETI, Gy. (1896): Adatok a magyar fauna braconidáinak ismeretéhez. Beiträge zur Kenntniss der ungarischen Braconiden. - Természetrajzi Füzetek 19: 165-186 [in Hungarian], 228-242 [in German]

TelengA, N. A. (1933): Einige neue Braconiden-Arten aus USSR (Hymenoptera). - Konowia 12: $242-244$.

TовiAs, V. I. (1957): New subgenera and species of the genera Bracon F. and Habrobracon Ashm. (Hymenoptera, Braconidae) from the steppe and desert regions of the USSR. - Entomologicheskoe Obozrenie 36(2): 476-500. [in Russian with English title and summary] 
Toвias, V. I. (1986): 149. Chelonus Jurine, 1801. Pp. 307-317. - In: Key to the Insects of the European Part of the USSR vol. III., Hymenoptera 4, 501 pp. [in Russian]

TовіAs, V. I. \& BeloковүLSкIJ, S. A. (1981): Records of braconid genera (Hymenoptera, Braconidae) new for the USSR and descriptions of new genera from Primorye Region. - Entomologicheskoe Obozrenie 60(2): 354-363. [in Russian with English title and summary]

Tовias, V. I. \& Beloковуцsкij, S. A. (2000): 6. Subfamily Braconinae. Pp. 109-192. - In: Key to the Insects of Russian Far East Vol. IV. Neuropteroidea, Mecoptera, Hymenoptera, Pt 4. Dal'nauka, Vladivostok, 651 pp. [in Russian]

Toвias, V. I. (2000): 4. Genus Chelonus [461-480. - In: Key to the Insects of Russian Far East Vol. IV. Neuropteroidea, Mecoptera, Hymenoptera, Pt 4. - Dal'nauka, Vladivostok, 651 pp. [in Russian]

WatanABe, C. (1970): Notes on braconid parasites of lepidopterous leaf-rollers with descriptions of two new species (Hymenoptera, Braconidae). - Mushi 43(10): 121-126.

Received May 29, 2017, accepted July 30, 2017, published March 30, 2018 